\title{
A SZENT ERZSÉBET MÓRAHALMI GYÓGYFÜRDŐ HELYI GAZDASÁGFEJLESZTÉSI SZEREPÉNEK ÉRTÉKELÉSE
}

\author{
Kis Krisztián - Förgeteg Lívia
}

\begin{abstract}
Absztrakt: Mórahalom Magyarország azon településeinek egyike, amely az elmúlt évtizedekben, jellemzően az elmúlt 15-20 évben, jelentős, mondhatni egyedülálló fejlódésen ment keresztül. A település az újonnan megjelenő és kibontakozó szükségletekkel összefüggésben képes volt meglévő, elsősorban természeti adottságainak (elsősorban a termálvíz), értékeinek újragondolására, tudatos döntésekkel és lépésekkel felhasználni azokat a helyi gazdaság fellendítése és az ott élök életminőségének javítása érdekében. Mórahalom turisztikai vonzereje alapvetően a gyógyfürdöre épül, ami az elmúlt másfél-két évtizedben a helyi fejlesztések alapjává vált. A megvalósított és folytatódó fejlesztések eredményeként a település olyan turisztikai értékajánlatot tud nyújtani a közönség számára, amely jelentős, évente növekvő mértékü turistaforgalmat generál, ami újabb munkahelyek létrejöttét és pótlólagos jövedelmeket eredményez a helyi gazdaságban.
\end{abstract}

\begin{abstract}
Mórahalom is one of the municipalities of Hungary which have undergone significant or, one could even say, unique progress in recent decades, typically in the last 15-20 years. In response to the newly emerging and unfolding needs, the town has been able to reconsider its existing assets, mainly its natural endowments (primarily thermal water), and to utilise them through conscious decisions and steps in order to boost the local economy and improve the residents' quality of life. The tourist attractiveness of Mórahalom is fundamentally built around the spa, which has become the basis for local developments in the past decade and a half or two decades. As a result of the implemented and ongoing developments, the town can present to the public a tourism product offer that generates a significant amount of tourist flow increasing year by year, and thus creates new workplaces and additional income in the local economy.
\end{abstract}

Kulcsszavak: gyógyfürdö, vonzerö, (egészség)turizmus, helyi gazdaság, fejlődés, identitás

Keywords: spa, attraction, (health) tourism, local economy, development, identity

\section{Bevezetés}

Mórahalom Magyarország azon településeinek egyike, amely az elmúlt évtizedekben, jellemzően az elmúlt 15-20 évben, jelentős, mondhatni egyedülálló fejlődésen ment keresztül. A település az újonnan megjelenő és kibontakozó szükségletekkel összefüggésben képes volt meglévő, elsősorban természeti adottságainak (elsősorban a gyógyvíz), értékeinek újragondolására, tudatos döntésekkel és lépésekkel felhasználni azokat a helyi gazdaság fellendítése és az ott élők életminőségének javítása érdekében.

Mórahalom 1950-ben alakult Szeged területéből és lett önálló település. Az azóta eltelt időben az eleinte szinte kizárólag mezögazdasággal foglalkozó tanyás település elsősorban turisztikai fejlesztéseinek köszönhetően, jelentősen átalakult, bővült, megújult. Mórahalom fejlődését reprezentálja, hogy 1989-ben városi rangot kapott, ma pedig önálló vonzáskörzettel rendelkező járási központ, vonzó turisztikai célpont.

Manapság Mórahalom ismertsége és gazdasága leginkább a Szent Erzsébet Mórahalmi Gyógyfürdő vonzerején és az arra épülő turisztikai szolgáltatásokon alapul. A gyógyfürdő története az 1960-as évekig nyúlik vissza, ekkor találták meg ugyanis a helyi, igen értékes termálvizet (később gyógyvíz minősítést kapott), amely 
mára a település legfontosabb értékévé vált. Az önkormányzat 1996-ban a településfejlesztés fö stratégiai irányának a fürdő- és az arra épülő turizmusfejlesztést jelölte meg. Ezen stratégiai célkitüzés megvalósításának első lépését az 1999-ben elkezdett fürdőfejlesztés jelentette.

Ezt követően a fejlesztések évröl-évre új színt vittek a medencekínálatba, az élményelemek és szolgáltatások választékába. A több mint ötven éves múltra visszatekintő fürdő 2006-ban elnyerte a Magyar Fürdőszövetség négycsillagos minősítését, ami akkor a legmagasabbnak számított. 2016-ban pedig már öt csillagot kapott gyógyfürdő kategóriában, az élményfürdő részleget pedig négycsillagosra minősítették. A létesítményben 2013 és 2016 között gyógyhely minősítési eljárás is folyt, melynek sikeres abszolválását követően 2016-ban hivatalosan is gyógyhellyé vált a fürdő, ami egyet jelent a minőséggel. Ugyanebben az évben a Magyar Fürdőszövetség szakmai támogatásával rendezett Év Fürdője közönségszavazáson „Az Év Feltörekvő Fürdőjének” a Szent Erzsébet Mórahalmi Gyógyfürdőt választották. Mórahalom ma elsősorban fürdővárosként ismert, hírnevét azonban nem csak a sokak által közkedvelt Szt. Erzsébet Gyógyfürdönek köszönheti, hanem a turisztikai kínálat folyamatos, tudatos bővítésének és fejlesztésének is. Természeti és ember alkotta vonzerök széles körét kínálja a város, ahol fiatal és idős, helybéli és turista egyaránt jól érezheti magát.

Tanulmányunk a Szent Erzsébet Gyógyfürdő Mórahalom gazdaságára gyakorolt hatásának elemzésével és értékelésével foglalkozik. Ennek keretében vizsgáljuk Mórahalom turistaforgalmának és turisztikai kínálatának fejlődését, jellemzőit, a gyógyfürdő gazdasági szerepét, különös tekintettel a helyi gazdaságserkentő, gazdaságélénkítő hatásokra, valamint a vállalkozások müködésére gyakorolt hatások számbavételére.

\section{A turizmus és területi fejlődés}

A turizmus széleskörüen elterjedt meghatározását a Turisztikai Világszervezet (WTO) és az Interparlamentáris Unió (IPU) által 1989-ben elfogadott Hágai Nyilatkozat a következőkben összegzi (IPU-WTO, 1989: 3): ,a turizmus magában foglalja a személyek lakó- és munkahelyén kívüli minden szabad helyváltoztatását, valamint az azokból eredő szükségletek kielégítésére létrehozott szolgáltatásokat."

Az elmúlt évtizedek során a turizmus a világ egyik leggyorsabban növekvö, sokszínü tevékenységi kört átfogó gazdasági ágazatává vált, amely szorosan kapcsolódik a fejlődéshez. Dinamizmusa révén a turizmus a társadalmi-gazdasági fejlődés kulcsfontosságú hajtóerejévé vált (UNWTO, é.n.), ami a magyar gazdaság jövöjében is kulcsszerepet játszik (Kulcsár, 2013). A turizmus,'mint a társadalmigazdasági fejlődés terméke a fenntartható gazdaságfejlesztés egyik húzóágazata, a terület- és településfejlesztés fontos eszköze (Aubert, 2002; Oláh, 2002). A turizmus országon belüli jelentőségét nagymértékben meghatározzák a turisztikai adottságok, a turisztikai potenciál (illetve ennek kihasználtsága), a turizmus gazdasági környezete (a kapcsolódó mikro- és makro struktúrákkal egyetemben), de legfontosabb szerepe a turizmusfejlesztés gazdaságpolitika prioritási sorrendjében elfoglalt helyének van (Kulcsár, 2013). 
A turizmus kialakulásában és fejlödésében kulcsfontosságú szereppel bírnak a vonzerők. Turisztikai vonzerő alatt, ami lehet természeti és ember alkotta vonzerö, azokat a dolgokat és viszonyokat értjük, amelyek a helyi gazdaságra és társadalomra számottevő mértékben befolyással bíró turistaérkezést indukálnak. Ellenkező esetben, ha az adott dolog nincs hatással a település gazdaságára, nem teremt foglalkoztatási és jövedelemszerzési lehetőséget a lakosság és vállalkozói szféra részére, úgy adott állapotában nem tekinthetö turisztikai vonzerőnek (Michalkó, 2005). A turizmusföldrajzi szakirodalomban találkozhatunk a turisztikai potenciál kifejezéssel, ami a turizmus fogadóképességének tárgyi feltételit jelenti, ami alapvetően határozza meg egy célterület turizmusba történö bekapcsolódását, illetve a már elért eredményeinek a fenntartását, bővítését (Michalkó, 2004). Annak érdekében tehát, hogy a turizmus betölthesse küldetését, sikeresen és fenntartható módon járuljon hozzá egy-egy település vagy térség fejlődéséhez mindenképpen szükséges, hogy a természeti és kulturális adottságok hasznosításának olyan struktúrája jöjjön létre, amely megfelelő kereteket jelent a turizmus számára. Az adottságok ugyanis önmagukban csak potenciális elönyöket, hasznosítható lehetőségeket jelentenek a települések és térségek számára. Valós erőforrássá akkor válnak, ha azokat ki is használják, azaz megtörténik azok konkrét, jelen esetben turisztikai hasznosítása. Ily módon a természeti és kulturális adottságok önmagukban nem jelentenek turisztikai vonzeröt, nem képesek tényleges jelentöségüket és funkcióikat érvényesíteni, mindez csak más tényezőkkel való összefüggésrendszerben realizálható (Kis-Tóth, 2016). Mindez a turisztikai fogadóképességben ölt testet, amelynek mennyiségi és minőségi színvonala alapvetően határozza meg a természeti és kulturális vonzásadottságok kihasználását. A vonzeröhöz, illetve a kereslethez igazodó fogadóképesség „felöleli a turisták elszállásolásával, étkeztetésével, vásárlásával, szórakozásával, sportolásával, egészségügyi és kulturális ellátásával, ipari és kereskedelmi szolgáltatásával, közlekedésével, utazásának szervezésével kapcsolatos elemeket" (Perczel, 2003: 450). Itt érdemes szólni a turisztikai termékröl, amelynek a turisztikai marketing szakirodalomban kétféle, mikro- és makroszintủ megközelítése különböztethető meg. Mikroszinten egy-egy idegenforgalmi vállalkozás által nyújtott konkrét szolgáltatást, szolgáltatáscsomagot is lehet turisztikai terméknek nevezni, makroszinten pedig a turisztikai termék tulajdonképpen magát a turisztikai desztinációt és annak a turista igényeinek kielégítésére kínált tematikus szolgáltatáshalmazait jelenti (Michalkó, 2011). A turizmus erőforrásai területi elhelyezkedésének vizsgálatában a földrajzi tér a kereslet számára vonzerőt és az adott desztináció által kínált terméket jelent. A turisztikai terméknek az a jellemzője, hogy a termelés és fogyasztás egy időben történik, és hogy a terméket helyben fogyasztják el, a teret sajátos funkcióval ruházza fel, s az adott földrajzi tér, téregység vonzeröi, turisztikai erőforrásai az adott helyi társadalom fontos fejlesztési tényezői is egyben (Aubert, 2001; Oláh, 2014). 
Mivel a turisztikai termék magja, lényege a vonzerő, ezért fontos feladat a vonzerő fokozása, fejlesztése, ami révén növelhető annak színvonala, illetve kiterjeszthető a vonzáskörzete; mindez jótékonyan hathat a turistaérkezésekre és az adott település, térség gazdasági eredményeire. A vonzerőt feltáró és annak értékesítését lehetővé tevő turisztikai fogadóképesség, illetőleg az azt meghatározó feltételrendszer elemeinek kiegyensúlyozott fejlesztése tehát növeli a turisztikai tevékenységek hatékonyságát, ezáltal hozzájárul a helyi gazdaság dinamizálásához. Ezt támasztja alá Michalkó (2005) véleménye is miszerint a turisztikai potenciál elemeinek forgalom generálásában testet öltő teljesítménye kimutatható hatással van a helyi gazdasági és társadalmi fejlödésre, ebböl kifolyólag alkalmas arra, hogy az adott hely, illetve térség fejlesztésének, versenyképessége javításának kulcsfontosságú tényezőjévé váljon. A turizmus sikere az előbbieken túl azonban egyéb tényezők függvénye is. Így fontos szerephez jut például a marketing (Kassai et al., 2009; Zsótér, 2007), a szervezés, az oktatás, az együttmüködés, az innováció (Kulcsár, 2013), a tevékenységek rendszerszemléletü koordinációját biztosító tervezés (Nagy, 2014), vagy az elöbbieket is magában foglaló turisztikai desztináció menedzsment (Lengyel, 2008; Raffay et al., 2013).

A turizmus szerepét és jelentőségét a hatásain keresztül közelíthetjük meg leginkább. A gazdasági hatásokon túl igen fontosak a turizmus társadalmi és természeti környezetre gyakorolt hatásai is, amelyek egyaránt lehetnek elönyösek és hátrányosak. A pozitív hatások erősítésének és a negatív hatások csökkentésének feltétele a turizmus tudatos (fenntartható) fejlesztése (Lengyel, 1997), ami által lehetőség nyílik a konfliktushelyzetek kezelésére, a harmonikus fejlődés megalapozására (Gál, 1999). A természeti és kulturális értékek turisztikai hasznosítása tehát mind gazdasági, társadalmi mind pedig környezeti szempontból fontos lehetöség. Azonban csak a gondos tervezés és az ezzel összefuiggő tevékenységek rendszerszemléletủ koordinációja biztosíthatja, hogy egy-egy település vagy térség számára a természeti értékeik gazdasági és társadalmi folyamatokba való integrálása az eröforrások és a tevékenységek olyan új, társadalmilag hasznos, gazdaságilag ésszerü, ökológiai szempontból megfelelö kombinációját hozza létre, ami hozzájárul e területi egységek fenntartható fejlödéséhez (Kis-Tóth, 2016). Elengedhetetlen tehát a vonzerő jobb és magasabb szintü hasznosítását biztosító turisztikai infrastruktúra olyan fejlesztése, amelyben a gazdasági, ökológiai és társadalmi szempontok érvényesítésének egyaránt fontos szerepe van (Perczel, 2003). Ezzel összefüggésben érdemes kihangsúlyozni, hogy a környezeti terhelés mértéke ma már minöségi kritérium, és hogy a lokális identitástudat és helyi kultúra megőrzése a turizmusfejlesztés egyetlen útja (Aubert, 2002).

Mára általánosan elfogadottá vált, hogy a turizmus mint az export alternatív formája (mivel nem a termék, hanem a kereslet változtat helyet) pozitívan járulhat hozzá a területi fejlődéshez, növelve a vállalkozói aktivitást, a foglalkoztatottságot és a jövedelmeket, bỏvülő szolgáltatásokat és a kedvezőtlen demográfiai folyamatok megállását eredményezve. Nem véletlen, hogy több (vidéki) településen a helyi gazdaság problémáinak orvoslására az önkormányzatok a turizmusban keresik a 
megoldást. Nem szabad azonban elfelejtenünk, hogy a turisztikai tevékenység versenyképességét és annak a helyi gazdasági fejlődésre gyakorolt hatását az eröforrások és a tevékenységek közötti kölcsönkapcsolatból adódóan számos tényező együtthatása határozza meg (Kis-Tóth, 2016). A turizmus interszektorális jellege miatt a területi tervezés valamennyi komponensével kölcsönhatásban áll, multiplikátor hatása révén eröteljes hatást gyakorol a rendszer egészére. Természetesen a települések adottságainak, elhelyezkedésének, elérhetőségének, vonzerejének és egyéb jellemzőinek függvényében ezek a hatások nagymértékben különbözhetnek. Mára a turizmus elismert településfejlesztö hatása mellett bizonyított annak terület- és vidékfejlesztésben játszott szerepe is (Aubert, 2011).

A turizmus helyi gazdaságra gyakorolt hatásának vizsgálata során fontos rögzítenünk, hogy a gazdasági bázis modell alapján a turizmusban tevékenykedő vállalkozások az erőforrásfüggő szektorba tartoznak, amelyek úgy képesek pótlólagos jövedelem bevonására a térségbe, hogy nem a termék kerül exportra, hanem annak vásárlói érkeznek a helyszínre. A turizmus gazdasági hatásai, azok jellege szerint, három kategóriába sorolhatók (Hustiné Béres, 2011): (1) direkt, (2) indirekt és (3) indukált vagy gerjesztett (multiplikátor) hatások. A gazdasági bázis elmélete az exporttevékenység bővítését és az importtevékenység szükítését feltételezi (Bajmócy, 2011; Székely, 2013). Ennek teljesülésekor várható, hogy az exportból származó, turisztikai vonzerő indukálta turistaforgalom bővüléséből adódó, térségbe áramló pótlólagos jövedelmek számottevő mértékü tovagyürüző hatásokat váltanak ki. Ezek a hatások a multiplikátorok révén, azaz az elsődleges és másodlagos multiplikátorhatáson keresztuil jönnek létre. A helyi gazdasági hatások fenti kategóriái a következőképpen értelmezhetők (Dusek-Lukovics, 2014): (1) direkt hatás: az adott gazdasági egység beruházásai és müködése miatt a helyi gazdaságban létrejövő kibocsátás, jövedelem és munkahelyek; (2) indirekt hatás: az adott gazdasági egység számára inputokat szolgáltató helyi vállalkozásoknál generált jövedelem és foglalkoztatás; (3) indukált hatás: a direkt és indirekt módon keletkező munkajövedelmek elköltése révén a multiplikátorhatással generált helyi jövedelem és foglalkoztatás; (4) illetve negyedikként értelmezhetők az ún. katalitikus hatások, amelyek az adott gazdasági egység müködése révén a helyi gazdaságban létrehozott változásokat takarják (pl. a megnövekedett befektetési vonzerö, látogatók vonzása, helyi imázs javulása, a helyi gazdaság szerkezetére, összetételére, a szolgáltatásokra gyakorolt hatások; ez a hatás lehet negatív is, ha pl. az adott gazdasági egység rontja az imázst vagy csökkenti a helyi vonzeröt). Az elsődleges multiplikátorhatás megfeleltethető az indirekt hatásnak, a másodlagos multiplikátorhatásban ugyanakkor keveredik az indukált hatás, valamint a katalitikus hatások egy része (Dusek-Lukovics, 2014).

A fentiek alapján, a térségen kívüli piacokra értékesítő ún. bázistevékenységek, illetve a turizmus jelentős mértékben képes dinamizálni a gazdaságokat, ezért érthetö, hogy a helyi és a regionális gazdaságfejlesztés kiemelt figyelmet szentel ezen tevékenységek ösztönzésének (Bajmócy, 2011; Lengyel-Rechnitzer, 2004). A gazdasági hatásokkal összefüggésben mindenképpen meg kell említeni, hogy azok akkor jutnak érvényre, amennyiben vannak helyi beszállítók és a jövedelmeket, 
illetőleg azok mind nagyobb részét helyben költik el, ellenkező esetben a jövedelem kiszivárog, illetve kiáramlik a térségből s a multiplikátorhatás csökken vagy nem is jön létre. Ezt továbbgondolva a turizmusra alapozott helyi gazdaságfejlesztés akkor tud sikeres lenni, ha mind nagyobb mértékben épül helyi termékekre (helyben termelt mezőgazdasági termékek, helyben készített élelmiszerek és ételek, helyi kézmüves termékek stb.) és helyi szolgáltatásokra (szállás, vendéglátás, programok, rendezvények stb.), csökkentve a jövedelmek kiáramlását, fokozva a tovagyürüzö, gazdaságdinamizáló hatásokat. Elöbbiek fontos szerepet tölthetnek be a helyi erőforrások fenntartható hasznosításában és a települések endogén alapokon nyugvó fejlődésének előmozdításában, továbbá a helyi gazdasági kontroll növelése révén erősíthetik a lokalizáció folyamatát, nagyobb fokú önrendelkezést biztosítva a lokalitások számára (Kis, 2014). Az ilyen lokális entitások sokkal inkább képesek saját értékeik és érdekeik mentén fejlődni, miközben egyre több lehetőségük adódik a megkülönböztetésre, valamint a helyi sajátosságok érvényre juttatására, ami által új pályára állítható, s dinamizálható a fejlődés (Kis-Pesti, 2015).

\section{Mórahalom rövid bemutatása}

Mórahalom Csongrád megye délkeleti részén, az 55-ös föút mentén, Szegedtől 20 kilométerre helyezkedik el. A település területe 8314 ha $\left(83,14 \mathrm{~km}^{2}\right)$, lakosainak száma 2017. január 1-jén 6290 fö volt, népsürüsége $75,6 \mathrm{fö} / \mathrm{km}^{2}$, ami jóval a vidékiség hazai népsürúségi alapkritériumának számító $120 \quad$ fö $/ \mathrm{km}^{2}$-es népességkoncentrációs határérték alatt van. Így tehát annak ellenére, hogy Mórahalom városi rangú település, népsürüsége alapján mindenképpen vidéki településnek számít, ami több vonatkozásban magán viseli a vidékiség jegyeit, ilyen pl. a tanyaközség múltból következö ma is kiterjedt tanyavilág.

Mórahalom 1892 óta egészen különleges utat járt be, s aligha akad a magyar Alföldön olyan település, amely a csaknem száz év alatt ilyen pályát futott be: a kizárólag tanyás településformától a várossá válásig (Juhász, 1992). A Szeged városa által 1892-ben Alsóközpont néven létesített közigazgatási kirendeltség, a lassan kiépülö tanyaközpont, majd Mórahalom község magvát képezte (Scheffer, 1992). A kis faluvá fejlődött tanyaközpontot 1950. január l-jén a Szeged határából kihasított 14624 kat. holdnyi területen önálló közigazgatású községgé nyilvánították (Juhász, 1992). A község ideiglenes neve 1950 augusztusáig Alsóközpont volt, majd a Mórahalom nevet kapta. Ily módon a település története 1950-ig Szeged város történetének része (G. Tóth, 1992). Mórahalmot 1970-ben nagyközségi, 1984-ben városi jogú nagyközségi, 1989-ben pedig városi rangra emelték (Martyin-Boros, 2012). Mórahalom fejlödését reprezentálja, hogy az egykori tanyaközpont mára valós térszervezö erövel bíró járásközponttá vált (1.ábra). 


\section{1. ábra: A Mórahalmi járás*}

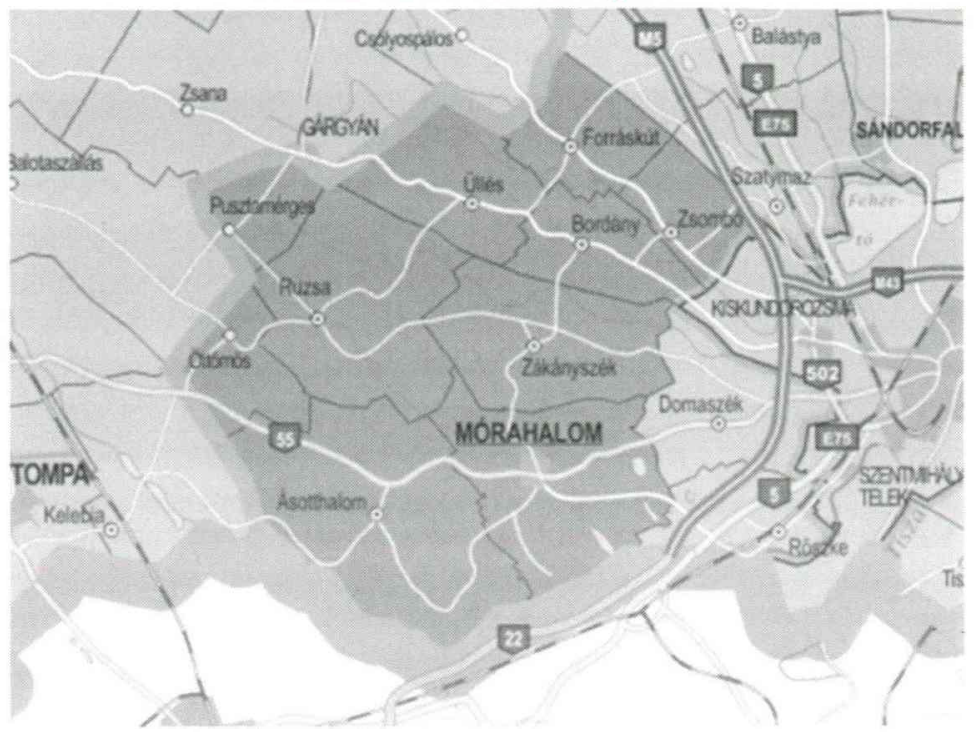

Forrás: http://www.jaras.info.hu/lap/morahalmi-jaras (2017.05.11)

*A járás települései, az egykori tanyaközpontok (egy város és 9 község alkotja): Ásotthalom,

Bordány, Forráskút, Mórahalom, Öttömös, Pusztamérges, Ruzsa, Üllés, Zákányszék, Zsombó.

Az önálló közigazgatási egységgé vált Mórahalom népességének négyötöde (79,2\%-a) élt tanyán. A Dél-Alföldön önállósult tanyaközségekben, Röszkét kivéve, sehol nem volt ilyen számottevő a belterületi lakosság aránya (20,8\%). 1960-ban Mórahalom népességének 70,7\%-a volt tanyai lakos. A község tanyai népessége 1970-ben 60,4\%, 1980-ban 41,1\%, 1990-ben 29,3\% volt (Scheffer, 1992). Mórahalom két településrésze ellentétes irányú népesedési folyamatok színtere volt. Miközben a belterületen élők száma is, aránya is nőtt (különösen szembetűnő ez a növekedés a hetvenes évtizedben, amikor is a belterületi lakosság 1212 fövel, 52,2\%-kal nőtt), a külterületi lakosoké csökkent (legnagyobb arányban, 34,4\%-kal, 1980 és 1990 között). 1949 és 1990 között a belterületi lakosság gyarapodásának (67,4\%) és a külterületen élö tanyai lakosság fogyásának mértéke közel azonos volt: $+67,4 \%$ illetve $-62,4 \%$. A rendelkezésre álló információk alapján tudható, hogy elsősorban a külterületrool érkezők gyarapították a „benn élők” lélekszámát, amelynek hátterében valószínüsíthetően a külterületi építési tilalom volt (Duró, 1992). A település kiterjedt tanyavilággal rendelkezik, hiszen a külterületen, tanyán élő lakosság aránya csaknem $25 \%$, míg a tanyák a település lakásállományának mintegy $30 \%$-át teszik ki. Ezen adatok is tükrözik a település tanyás-vidékies jellegét.

Az előbbi folyamatokkal egy időben 1950 után, különösen az '50-es, '60-as években, zuhanásszerủen, 868 fővel csökkent a lakosság száma (szemben az 19001949 közötti fél évszázad alatti ütemes növekedéssel). A folyamat később mérséklődött, de még így is 1949 és 1990 között mintegy 1200 fövel csökkent a lakosságszám, ami a fiatalabb korosztályhoz tartozók elvándorlása miatt a helyben 
maradt népesség elöregedését eredményezte. Ez utal a település népességmegtartó képességének csökkenésére, arra az Alföld-szerte megfigyelhetö jelenségre, ami a központi hatalom 1949-től folytatott gazdaság-, agrár- és településpolitikájára, illetve a helyi paraszttársadalom egy részének, akkori elitjének szélsőségesen durva politikai uildözésére vezethető vissza (Belényi, 1992). A népesség fogyása az '50-es évektöl az ezredfordulóig tartott. Ezt követően a népesség a legutóbbi, 2017. január 1-jei mérésig növekedett (2. ábra). A népességnövekedés hátterében a pozitív vándorlási egyenleg áll (sajnos a természetes szaporodás egyenlege negatív előjelü), ami a város népességvonzó képességére utal.

\section{2. ábra: Mórahalom lakónépességének változása 1870 és 2017 között}

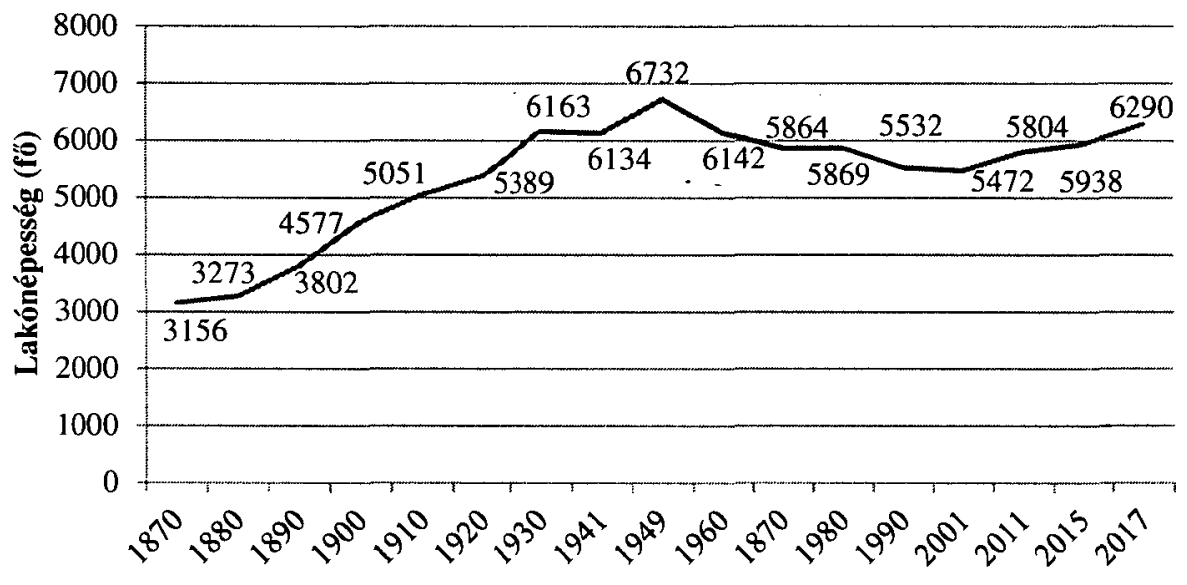

Forrás: http://nepesseg.com/csongrad/morahalom (2017.05.12.)

Mórahalom gazdasági életében az '50-es és '60-as években is a mezőgazdaság játszotta a meghatározó szerepet. Mindezt jól mutatja, hogy 1960-ban az aktív keresőnépesség 78,9\%-a, 1970-ben 67,1\%-a dolgozott a mezőgazdaságban (Belényi, 1992). Ma már jóval differenciáltabb a foglalkoztatási szerkezet, amit egyre inkább a turizmus jelentős munkahelyteremtő és gazdaságszerkezet-átalakító hatása befolyásol (Martyin-Boros, 2012). Amint azt a város integrált településfejlesztési stratégiája is megállapítja: „... a turizmus növekedése a térségben újabb munkahelyek létrejöttét generálja. A turizmus életminőség javító és gazdaságélénkítő hatása vitathatatlan a térségben." (ITS 2015: 13). Összességében elmondható, hogy ma „Mórahalom ismertsége és gazdasága leginkább a turizmuson, azon belül is a Szent Erzsébet Mórahalmi Gyógyfürdö vonzerejên és a rá épülö turisztikai szolgáltatásokon alapul", amit a folyamatosan fejlődő és bővülő öko-, agrár- és kulturális turisztikai szolgáltatók által kínált programok egészítenek ki. A turizmus jelentőségét tükrözi az önálló tematikus célként való megjelölés Mórahalom Város Integrált Településfejlesztési Stratégiájában, valamint a célterülethez kapcsolódóan a 2014-2020-as fejlesztési idöszakra tervezett projektek volumene is (ITS, 2015: 22). 


\section{Anyag és módszer}

Kutatásunk átfogó célja a Szt. Erzsébet Mórahalmi Gyógyfürdő helyi gazdaságra gyakorolt hatásainak elemzése és értékelése. Ennek keretében vizsgáljuk Mórahalom turisztikai kínálatának és vendégforgalmának ezredfordulót követő fejlődését és jellemzöit; a kínálat változásának értékelése során elkészítettük a település áttekintő vonzerőleltárját, ami a turisztikai termék komplex fejlesztésének alapja. Vizsgáljuk továbbá a gyógyfürdő direkt és katalitikus gazdaságélénkítő hatásait, valamint a gyógyfürdőfejlesztés vállalkozásokra gyakorolt hatását.

Kutatásunkhoz primer és szekunder módszereket vettünk igénybe. A turisztikai kereslet és kínálat, valamint a gyógyfürdö gazdasági hatásainak vizsgálatához szükséges adatok az Országos Területfejlesztési és Területrendezési Információs Rendszerből (TeIR), valamint a Móra-Tourist Nonprofit Kft., mint helyi turisztikai desztináció menedzsment (TDM) szervezet adatbázisából származnak, de felhasználtuk a helyi és térségi média anyagait is. A vonzerőleltár elkészítése során Mórahalom Város Önkormányzatának honlapja és a Szt. Erzsébet Gyógyfürdő internetes felületei, valamint a Móra-Tourist Nonprofit Kft. által a rendelkezésünkre bocsátott rendezvénynaptárak voltak segítségünkre, illetve kutatásunkat személyes tapasztalataink is segítették. A fürdőfejlesztés vállalkozásokra gyakorolt hatásainak értékeléséhez szükséges adatokat 2016 októberében elvégzett kérdőíves felméréssel a gyógyfürdőben, illetve annak közvetlen környezetében elhelyezkedő vállalkozások tulajdonosainak bevonásával állítottuk elő. Leginkább arra voltunk kíváncsiak, hogy a fürdöfejlesztés miképpen befolyásolta, illetve befolyásolja a vállalkozások alapítását, müködését, bővítését és fejlesztését. Vizsgáltuk továbbá az árbevételre, az eredményre és a foglalkoztatásra gyakorolt hatást.

\section{A turisztikai kereslet változásának vizsgálata: vendégforgalom és a vendégéjszakák számának alakulása}

Mórahalom olyan turisztikai lehetőségekkel, természeti és ember alkotta vonzerökkel rendelkezik, melyek segítségével nemcsak a régióban, hanem egész Magyarországon turisztikai hírnévre tett szert, sőt a határ menti fekvésének köszönhetően főként Szerbiában, de Romániában is ismert turisztikai célpont. A kisváros az ezredfordulót követően, a fürdőfejlesztésekkel párhuzamosan vált híressé. A fürdőkomplexum javította a település turisztikai fogadóképességének tárgyi feltételeit és jelentősen növelte a város vonzerejét avval, hogy olyan komplex szolgáltatást nyújtó létesítmény jött létre, ami érdemben növelte a településre érkező turisták számát.

A fürdőfejlesztések hatását és eredményességét illusztrálja, hogy míg a 2004-es arculatváltás évében még csak 92409 fỏ pihenni, gyógyulni vágyót fogadott a fürdö, addig ez a szám mára már meghaladja az évi 300000 látogatót. A létesítmény és a település fejlesztése, a szolgáltatások bỏvítése, a marketingtevékenység fokozása mind-mind pozitívan hatottak a turistaforgalom fejlödésére, melyek növelték a szálláshelyek iránti keresletet is. Az 1. táblázat adatai a vendégforgalom jelentős növekedését mutatják, hiszen 2000 és 2014 között csaknem ezerkétszázszorosára 
bővült a településen megszállók száma. A szálláshelyeken regisztrált vendégforgalom növekedése azonban nem volt töretlen. A 2004-es nagy volumenü fürdőfejlesztés minden bizonnyal fontos szerepet játszott abban, hogy 2007-ig a vendégforgalom a háromszorosára növekedett, azonban a 2008-ban kirobbant gazdasági világválság következtében a vendéglétszám mintegy négyszáz fővel esett vissza a 2009-2010-es évekre. Ez visszavezethető arra, hogy a válságban csökkentek a szabadon elkölthetö jövedelmek, ami a turizmusra fordított lakossági költések visszaesését eredményezte. A vendégforgalom 3,5-4\%-os visszaesése két évig tartott, hiszen 2011-ben ugrásszerüen, csaknem 8000 fövel, megnött a szállóvendégek száma. Ezt követően a növekedés, bár kisebb mértékben, de folytatódott. A táblázat adataiból megállapítható, hogy a településen megszálló vendégek meghatározó (75-80\%) része belföldröl érkezik. Ennek megfelelően a Mórahalomra érkező turisták szálláskeresletét a belföldi vásárlóerö határozza meg.

\section{1. táblázat: A vendégek számának alakulása kereskedelmi és egyéb} (magán) szálláshelyeken

\begin{tabular}{|c|c|c|c|}
\hline \multirow{2}{*}{ Év } & \multicolumn{3}{|c|}{ Vendégek száma } \\
\cline { 2 - 4 } & Belföldi vendégek (fö) & Külföldi vendégek (fö) & Összesen (fö) \\
\hline $\mathbf{2 0 0 0}$ & 21 & 3 & 24 \\
\hline $\mathbf{2 0 0 1}$ & 97 & 4 & 101 \\
\hline $\mathbf{2 0 0 2}$ & 317 & 49 & 366 \\
\hline $\mathbf{2 0 0 3}$ & 1597 & 372 & 1969 \\
\hline $\mathbf{2 0 0 4}$ & 2495 & 626 & 3121 \\
\hline $\mathbf{2 0 0 5}$ & 4533 & 775 & 5308 \\
\hline $\mathbf{2 0 0 6}$ & 5067 & 2137 & 7204 \\
\hline $\mathbf{2 0 0 7}$ & 8036 & 1332 & 9368 \\
\hline $\mathbf{2 0 0 8}$ & 9511 & 1305 & 10816 \\
\hline $\mathbf{2 0 0 9}$ & 8940 & 1447 & 10387 \\
\hline $\mathbf{2 0 1 0}$ & 8914 & 1500 & 10414 \\
\hline $\mathbf{2 0 1 1}$ & 15929 & 2799 & 18728 \\
\hline $\mathbf{2 0 1 2}$ & 19499 & 4213 & 23712 \\
\hline $\mathbf{2 0 1 3}$ & 19969 & 5884 & 25853 \\
\hline $\mathbf{2 0 1 4}$ & 22314 & 6558 & 28872 \\
\hline
\end{tabular}

Forrás: TelR

A településen eltöltött vendégéjszakák számát vizsgálva megállapítható, hogy a szállóvendégek számának alakulásához hasonló tendencia rajzolódik ki (3. ábra). 2000-töl 2008-ig növekedés, majd 2009-2010-ben visszaesés, 2011-től pedig dinamikus bővülés figyelhetö meg. 


\section{3. ábra: A településen eltöltött vendégéjszakák száma a kereskedelmi és egyéb szálláshelyeken (2000-2015)}

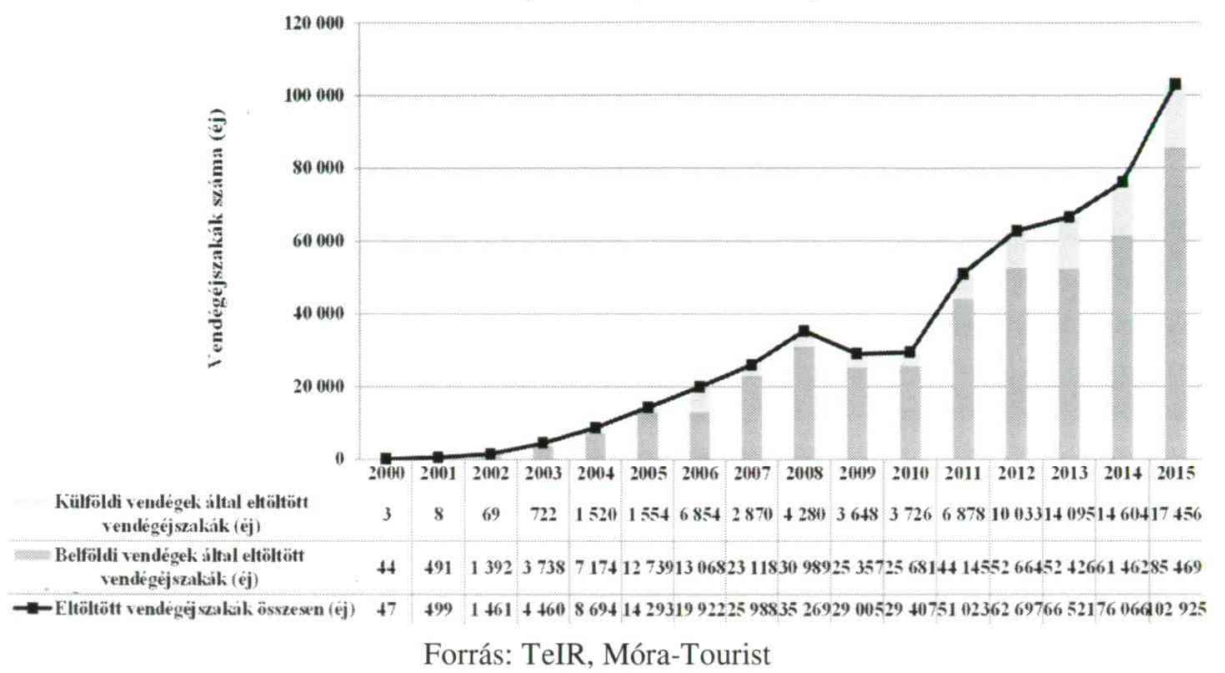

2000 és 2014 között több mint 1 600-szorosára nőtt a vendégéjszakák száma, ami meghaladja a szállást igénybe vevők 1200 -szoros növekedését. Ez az átlagos tartózkodási idő növekedésével magyarázható (4. ábra). Az adatok alapján a vizsgált időszakban összességében $25 \%$-kal bővült az egy före eső vendégéjszakák száma, ugyanakkor a válság évei (2008, 2009) után, 2010 és 2013 között kismértékben csökkent, majd 2014-ben újból nőtt, ami mindenképpen biztató.

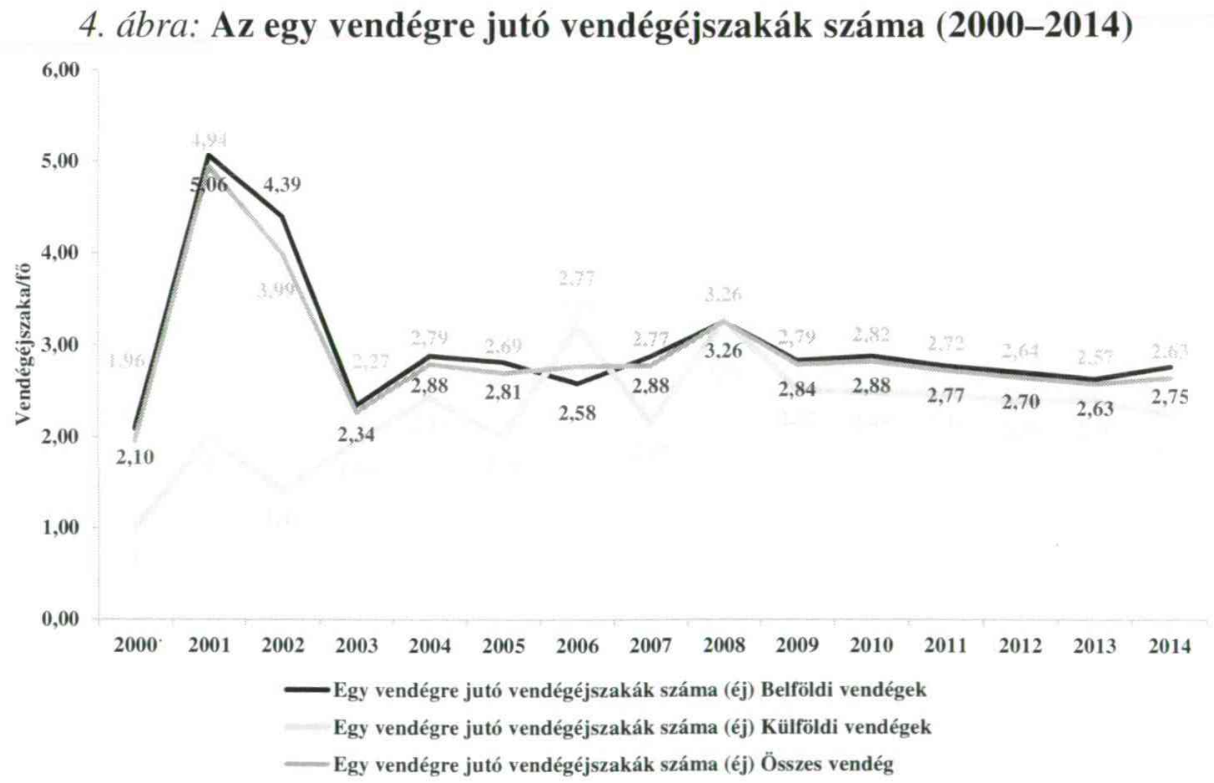

Forrás: TeIR 
Az átlagos vendégéjszakák utóbbi években tapasztalt csökkenő tendenciája sem a szállásadóknak, sem a településnek nem tettek jót, hiszen a csökkenő tartózkodási idő kevesebb költést von maga után, ami mérsékli a turizmus helyi gazdaságra gyakorolt pozitív hatásait. További hátrány a szállásadók számára, hogy kiszámíthatatlanabbá és nehezebben szervezhetôvé válik szobakapacitásaik kihasználása. Nyáron, a föszezonban ez a jelenség kevésbé érezteti hatását, mivel a folyamatos turistaérkezéseknek köszönhetően szinte maximális a kereskedelmi és egyéb szálláshelyek kapacitáskihasználtsága.

Előbbiek felhívják a figyelmet arra, hogy nem elég a látogató- és turistaforgalom bővülése, szükséges a településen eltöltött idő és az egy före eső vendégéjszakák számának növelése is. Ez a felismerés fontos szerepet játszik a turisztikai kínálat létrehozásakor, a fogyasztói igényekhez illeszkedő, a település értékeire és érdekeire tekintettel lévő turisztikai attrakciók és szolgáltatások fejlesztésekor, ami növelni tudja nem csak a látogatószámot, hanem a szállásadóknál töltött vendégéjszakák számát is.

Minden szálláshelyen eltöltött vendégéjszaka után idegenforgalmi adót (IFA) kell fizetnie minden 18. életévét betöltött személynek. Mórahalmon 2000-ben az adó mértéke $100 \mathrm{Ft}$ volt, ami az évek során 2015 -re $500 \mathrm{Ft}$-ra nőtt. Az utóbbi években az eltöltött vendégéjszakák számának rohamos növekedésével, a kereskedelmi és magánszálláshelyek által az önkormányzat részére fizetendő idegenforgalmi adó (IFA) mértéke és összege is jelentősen emelkedett. Ennek eredményeként az önkormányzat idegenforgalmi adóbevétele tizenöt év alatt négy nagyságrenddel, közel a nyolcezerszeresére nőtt, összege mintegy 40 millió Ft (38 $975567 \mathrm{Ft}$ ).

\section{Mórahalom turisztikai kínálatának vizsgálata: vonzerők és a szálláshelyek számának alakulása}

A település rendelkezésére álló nagyszámú vonzerönek, természeti, táji, kulturális és épített eröforrásainak és értékeinek is köszönhetöen Mórahalom napjainkban sokszínü, változatos élményeket és turisztikai lehetőségeket tud nyújtani az ideérkezö turisták számára. Lévén a turisztikai termék, illetve a turisztikai kínálat veleje, magja a vonzerő, ami a turistákat arra motiválja, hogy a helyszínre utazzanak, szükségesnek tartottuk egy áttekintő vonzerőleltár elkészítését, amely Mórahalom valamennyi turisztikai szempontból lényeges értékét tartalmazza. A vonzerőket, eredetük és jellemzőik alapján, csoportosítva mutatja be a 2. táblázat. 


\section{2. táblázat: Mórahalom természeti és ember alkotta vonzeröi}

\begin{tabular}{|c|c|c|}
\hline Természeti értékek, vonzerők & \multicolumn{2}{|c|}{ Ember alkotta értékek, vonzerők } \\
\hline $\begin{array}{l}\text { Tavak, vizek: } \\
\text { - Madarász-tó } \\
\text { - Nagyszéksós-tó } \\
\text { - Termálvíz } \\
\text { - Gyógyvíz: Erzsébet gyógyvíz } \\
\text { (1999), Árpád gyógyvíz (2009), } \\
\text { Szent László gyógyvíz (2013), } \\
\text { Hunyadi Mátyás gyógyvíz } \\
\text { (2013) } \\
\text { Növény-és állatvilág: } \\
\text { - Öshonos állat- és növényfajok } \\
\text { - Védett állat- és növényfajok } \\
\text { Védett terülletek: } \\
\text { - Csipak-semlyék } \\
\text { - Tanaszi-semlyék } \\
\text { - Bivalyrezervátum } \\
\text { - Körös-éri Tájvédelmi Körzet } \\
\text { (Kiskunsági Nemzeti Park) }\end{array}$ & $\begin{array}{l}\text { Vallási helyek: } \\
\text { - Szent László király templom } \\
\text { - Jehova Tanúi - Királyság-terme } \\
\text { Népi kultúra: } \\
\text { Gasztronómia: } \\
\text { - Kralleri Borház } \\
\text { - Rétesház } \\
\text { - Mórahalmi kecskesajt } \\
\text { - Mórahalmi Rózsa-rétes } \\
\text { - Homokháti méz } \\
\text { - Mórahalmi savanyúság } \\
\text { - Mórahalmi száraz tészta } \\
\text { Közösségi és múvelödési } \\
\text { létesítmények: } \\
\text { - Aranyszöm Rendezvényház } \\
\text { - Béróhögyi Sportközpont } \\
\text { - Futó-Dobó Lovasközpont } \\
\text { - Homokháti Emlékház } \\
\text { - Nagyszéksósi Kulcsosház } \\
\text { - Sportcentrum } \\
\text { - Tóth Menyhért Városi Könyvtár } \\
\text { - Zöld Közösségi Ház és Erdei } \\
\text { Iskola } \\
\text { Fürdỏ, wellness központ: } \\
\text { - Szent Erzsébet Gyógyfürdö } \\
\text { - Elixír Medical Wellness Hotel }\end{array}$ & $\begin{array}{l}\text { Rendezvények és fesztiválok: } \\
\text { - „Csobbanj Európával” roadshow } \\
\text { - Bivalyfesztivál } \\
\text { - Díjugrató verseny } \\
\text { - Gyorsasági roncsderby verseny } \\
\text { - Homokháti búcsú } \\
\text { - Homokháti Sokadalom } \\
\text { - Idösek napja } \\
\text { - Mazsorett gála } \\
\text { - Motocross Track salakmotor verseny } \\
\text { - Nemzetközi Néptánc Fesztivál } \\
\text { - Néptánc gála } \\
\text { - Országos kirakodó és állatvásár } \\
\text { - Pálinkaverseny és tepertő fesztivál } \\
\text { - Patkó Lovas Színház } \\
\text { - Rétesfesztivál } \\
\text { - Rotary Jótékonysági Futónap - } \\
\text { - Természeti túrák (Bunkertúra, } \\
\text { Gombatúra, Csillagtúra stb.) } \\
\text { - Ugrókötél gála } \\
\text { - Városkarácsony } \\
\text { Történelmi és kulturális örökség: } \\
\text { - I. Világháborús emlékmü } \\
\text { Kiállítóhelyek: } \\
\text { - Mini Hungary Park } \\
\text { - Babamúzeum }\end{array}$ \\
\hline
\end{tabular}

Mórahalom és környéke kimagaslóan sok védett növény- és állatfajjal, természetvédelmi területtel rendelkezik. A Tanaszi-semlyék a város és a szerb határ közötti területen fekszik, ahol olyan ritkaságok, mint a pókbangó (Ophrys sphegodes), a mocsári kosbor (Orchis laxiflora) és a tarka sáfrány (Crocus reticulatus) lelhető fel. A Csipak-semlyék növénytani értékei ugyancsak kiemelkedőek. Nagy számban fordul itt elő a szibériai- és a fátyolos nőszirom (Iris sibirica, Iris spuria), a kornistárnics (Gentiana pneumonanthe), a mocsári kosbor (Orchis laxiflora) és szálanként a pókbangó (Ophrys sphegodes). A Madarász-tó Mórahalomtól délre, a szerb határtól egy kilométerre található, egy hosszan elnyúló buckaközt tölt ki. A sekélyebb partjain ritkaságnak számító gulipánok (Recurvirostra avosetta) fészkelnek, de költö fajként megtelepedett itt a bütykös hattyú (Cygnus olor) is. Vidrával (Lutra lutra) is találkozhatunk, ami a tájvédelmi körzet különleges értéke. A Bivalyrezervátum és a Nagyszéksós-tó a Röszke felé vezető út mellett terül el. A bivalyok 2008-ban érkeztek a településre egy sikeres pályázatot követően. A beruházás célja a Nagyszéksós-tó egykori jellegének visszaállítása, a vizes élőhely rehabilitáció legeltetésre alapozott ökológiai gazdálkodással, élőhely-rekonstrukciót megvalósító bemutató hely kialakítása, a terület széleskörü tudományos kutatási feltételeinek megteremtése, valamint a turizmus bővítése volt. A rezervátum mára már nagy sikereket könyvelhet el, hiszen csökkent a náddal borított területek 
kiterjedése, nőtt a vízfelület, visszatértek a területet elhagyó madárfajok, s újak is megjelentek, valamint a növényzet újrajelenése is bizonyítéka a program sikerének.

A vonzerök a turisztikai kínálat legfontosabb összetevöi, amelyek a turistákat a helyszín meglátogatására ösztönzik. Habár Mórahalom legfőbb attrakciója a gyógyfürdő, ahhoz, hogy a település vonzereje bővüljön szükséges a vonzerők, illetve turisztikai termék egyéb elemeinek fejlesztése is. Ennek céljából hozták létre 2014-ben a Mini Hungary Parkot, amely az 1910-es Magyarország építészeti szimbólumait, történelmi emlékeit foglalja magába 1:25-ös méretarányú makettek formájában. A Zöld Közösségi Ház és Erdei Iskola túrákat, foglalkozásokat szervez a természetet kedvelőknek, kutatóknak, emellett általános és középiskolások kirándulóhelyéül is szolgál.

A településen a sport szerelmesei is bőven válogathatnak a lehetőségek közül, hiszen a Béróhögyi Sportcentrumban a salakmotorozást, a Futó-Dobó Lovasközpontban pedig a lovaglást és díjugratást lehet kipróbálni. A Móradombi körúton lévő sportkomplexumnál két élőfuives és egy müfuves futballpálya található, a létesítmény emeletén pedig egy korszerü, gazdag fitneszpark várja a vendégeket. A sportpályák mellett jelenleg zajlik egy szabványméretü sportcsarnok és egy uszoda építése is. A színházrajongók is elöszeretettel látogatják a várost, hiszen a nyári szezonban lovas színházi előadásokat lehet megtekinteni a Futó-Dobó Lovasközpontban a Nemzeti Lovas Színház színészeinek előadásában. A 2016-os évben öt különböző előadást tartottak, ez kilenc teltházas előadást jelentett, amely ca. 9000 fös nézösereget jelent. A nyár elmúlásával sem kell azonban a színház szerelmeseinek búsulnia, hiszen az Aranyszöm Rendezvényház vendégszínházak előadásával színesíti a repertoárt. Láthatunk színdarabot a Gergely Theater, a Szigetszentmiklósi Színház és a Katona József Színház előadásában is.

A vonzerők körét bővítik a turizmusban egyre jelentősebb szerepet betöltő rendezvények is, melyek színesítik, mozgalmassá és élővé teszik a helyi turisztikai értékek bemutatását, fokozva ezzel a település vonzerejét. A különbözö programok lehetővé teszik a település hagyományainak, kulturális örökségének, a kisvárosi vendégszeretetnek a bemutatását, gazdagítva a turisták időtöltési és szórakozási lehetöségeit. Emellett lehetőséget adnak a helyi lakosok találkozására, bevonására, tevékeny részvételére a programokban, a turisztikai szervezetek önkormányzattal, helyi gazdálkodókkal, vállalkozásokkal, civil szervezetekkel való együttmüködésére, továbbá a helyi kultúra különböző elemeinek (népi kultúra, mezőgazdasági termékek, ételek, kézmüves termékek) gazdasági hasznosítását is elösegítik, miközben formálják a helyi identitást és a település arculatát. Számos program népszerüsíti a település hagyományait, gasztronómiai termékeit, a kisváros vendégszeretetét. A gasztrorendezvények minden évben nagy sikert aratnak, ilyen például a Bivalyfesztivál, a Rétesfesztivál, a Pálinka- és tepertőfesztivál. A pezsgö városi programokba a helyi lakosságot is bevonják, hiszen fontos a városvezetés számára, hogy a helyiek, a szállásadók, a vállalkozók, a gazdálkodók sikeresen együtt tudjanak múködni a városba érkezök igényeinek minél magasabb szinten történő kielégítése érdekében. 
Az elmúlt években jelentősen bövült a településen megrendezett rendezvények száma (5. ábra), melyek többsége a városközpontban és annak közvetlen környezetében került megrendezésre.

\section{5. ábra: A településen megrendezett események számának havonkénti} alakulása (2013-2016)

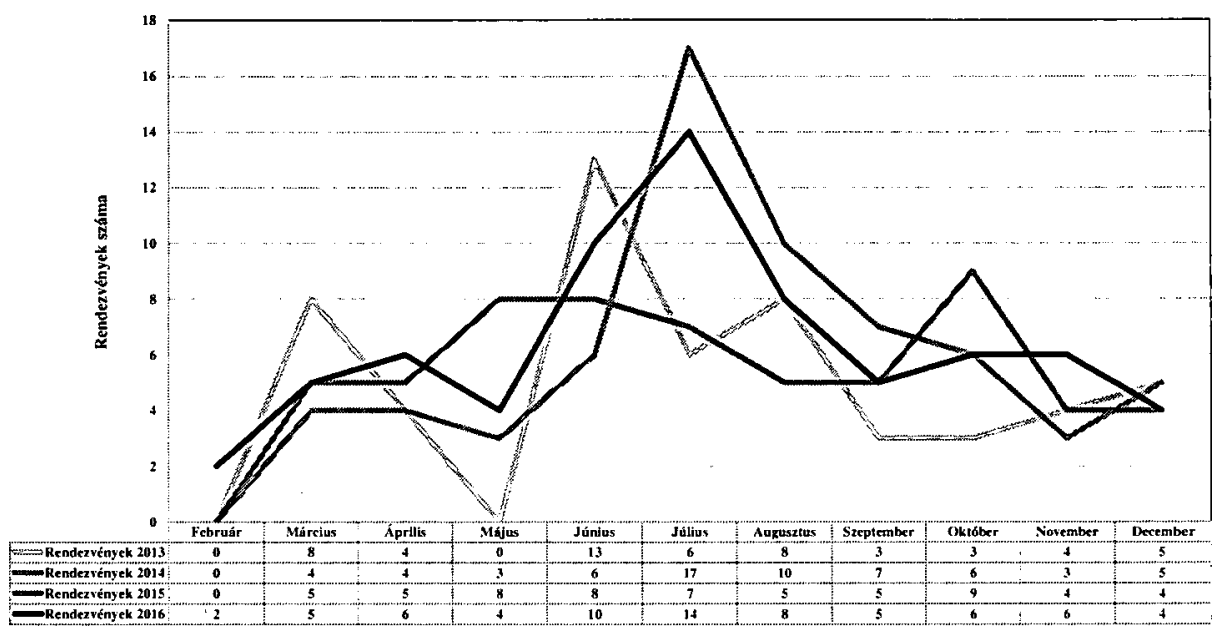

Forrás: Móra-Tourist

Manapság éves szinten hetven körüli rendezvény kerül megszervezésre a településen, ami átlagosan havi hat alkalmat jelent, de az ábráról leolvasható, hogy az események száma a nyári hónapokra csúcsosodik ki. Ezzel együtt látható, hogy ma már minden hónapban szerveznek valamilyen programot a településen, melyeket nagyrészt hétvégére, hosszú hétvégére, ünnepnapokra terveznek. Amíg a kétezres évek elején még elenyésző számú és egyszínü volt Mórahalom eseményrepertoárja, addig mára már sok különböző témájú és fajtájú, színes program közül választhatnak a helybéliek és az idelátogató turisták egyaránt. A hagyományosnak minősülö ünnepi megemlékezések, a majális, a városnap és a városkarácsony mellett, ma már olyan különlegességeken is részt lehet venni, mint a „Csobbanj Európával” Roadshow, a Global Wellness Day, a Szent Iván éjjele vagy a strandok éjszakája, melyek kifejezetten a fürdöhöz kapcsolódva, annak területén kerülnek megrendezésre.

A gyógyfürdöt a különböző létesítmények, szolgáltatások és rendezvények mellett olyan elismerések, kitüntetések is gazdagítják, elismerve a fejlesztések és az itt folyó munka értékét, mint a gyógyhelynek való minősítés, melyet 2016-ban szerzett meg a Szt. Erzsébet Mórahalmi Gyógyfürdő. A szigorú minősítési eljárásnak eddig huszonhat gyógyhely tett eleget az országban. A Magyar Fürdőszövetség létrehozta a nemzeti tanúsító védjegyrendszert, melynek keretében a mórahalmi gyógyfürdő négycsillagos gyógyfürdő minősítést kapott 2006-ban. A négy csillag akkor a legjobbnak számított, azonban 2014-ben ötcsillagos tanúsító rendszer került bevezetésre, amely öt évre szóló védjegyhasználattal párosul. A mórahalmi fürdöt 2016-ban minősítették újra, mely során ötcsillagos gyógyfürdő és négycsillagos 
élményfürdő minősítést szerzett. 2016-ban második alkalommal rendezte meg a termalfurdo.hu a Magyar Fürdőszövetség szakmai támogatásával az Év Fürdője szavazást, melyen az „Év Fürdőjét”, az „Év Feltörekvő Fürdőjét” és a „Helyiek Kedvenc Fürdőjét" keresték. (A kategóriákba történő besorolás a medencék száma, a település mérete és a fürdő ismertsége alapján történt.) A Szent Erzsébet Mórahalmi Gyógyfürdő a verseny keretében története egyik legnagyobb sikerét könyvelhette el, hiszen közönségszavazatok alapján „Az Év Feltörekvő Fürdője 201.6" címet nyerte el. Ezzel olyan versenytársakat utasított maga mögé mint a makói Hagymatikum, a Szentesi Üdülőközpont, a Csongrádi Gyógyfürdő és Uszoda, a hódmezövásárhelyi Török Sándor Strandfürdö és Gyarmati Dezsö Sportuszoda, valamint a Sziksósfürdői Strand és Kemping.

\section{6. ábra: A kereskedelmi és egyéb szálláshelyek számának alakulása}

(2000-2014)

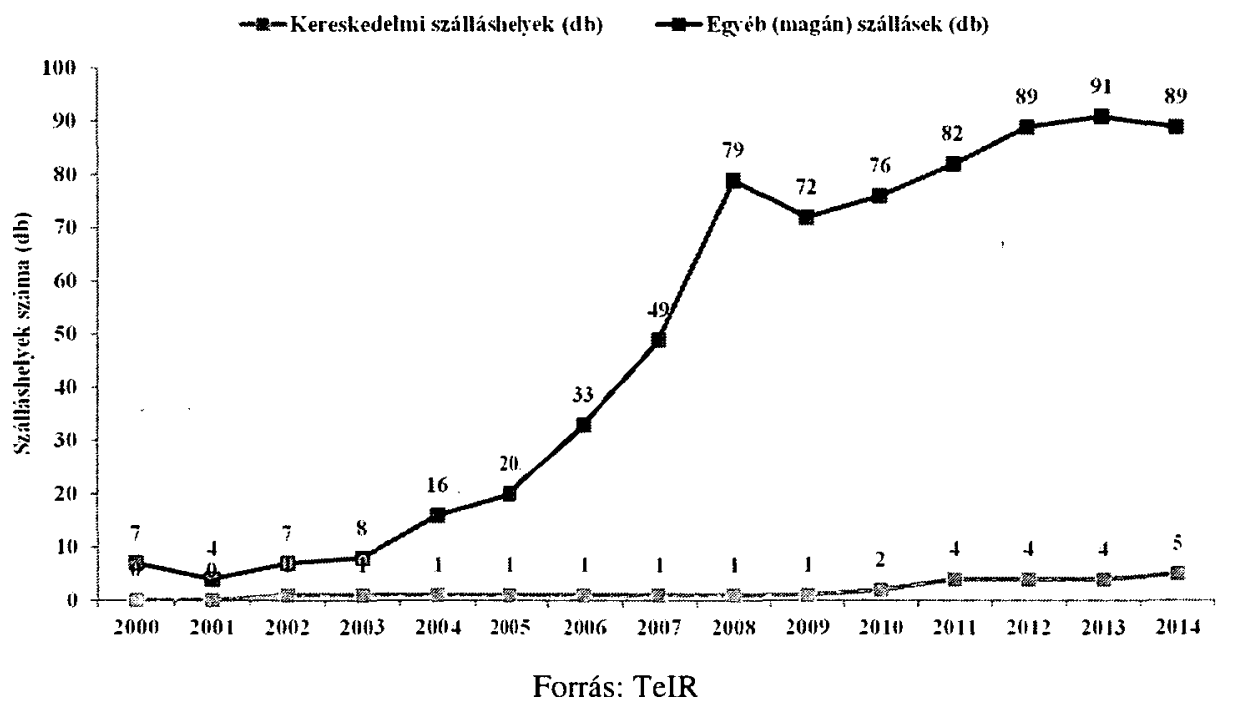

A vonzerők mellett a turisztikai kínálat fontos összetevöi a szálláshelyek, illetve az általuk elérhető szolgáltatások, melyek hozzájárulnak a településen eltöltött idő növeléséhez, ezáltal a turizmusból származó bevételek bővüléséhez. A 2000-es évek óta folyamatosan növő turistaforgalom, új, magasabb minőségü kereskedelmi és magán (egyéb) szálláshelyek létrehozását idézte elö. A legelső kereskedelmi szálláshelyet, a Thermál Panziót 2002-ben építették, ezt a 2010-ben megnyíló Colosseum Hotel, majd a Tourinform Iroda által üzemeltetett apartmanok követték. A város legújabb kereskedelmi szálláshelyét 2015 októberében nyitották Elixír Medical Wellness Hotel néven. A keresletnövekedésre tehát a kereskedelmi- és magánszállásadók egyaránt reagáltak. A bővülő igények tehát bővülő kínálatot és új vállalkozások megjelenését generálták, köszönhetően a helyi turisztikai piac kedvezö jövedelmezőségi lehetőségeinek. A szálláshelyek számának 2000 és 2014 közötti változását mutatja be a 6 . ábra. 
$\mathrm{Az}$ adatok szerint a vizsgált időszak alatt a kereskedelmi egységek száma nulláról ötre nőtt, míg az egyéb (magán) szálláshelyek száma több mint a tizenkétszeresére, 7-röl 89-re emelkedett. Ez annak tudható be, hogy a helyiek, lakosok és vállalkozások egyaránt felismerték a turizmusban rejlő potenciált, ezért a meglévő ingatlanjaikat, azok kihasználatlan helyiségeit, esetenként kifejezetten erre a célra létrehozott és kialakított épületeket a turizmus szolgálatába állították nyereség elérése céljából. A mórahalmi szálláshelyek bö választéka között mindenki megtalálhatja a magának valót. A szálláshelykínálat növekedésével nőtt a szállásadók közötti verseny is, ami új típusú, minőségi szállóhelyeket generált. Így ma már pihenhetünk jakuzzis luxus apartmanokban, tóparti, csendes tanyasi vendégházban vagy akár panelházban kialakított szálláshelyen. A turisták kikapcsolódásához, pihenéséhez és gyógyulásához az év minden napján nyitva tartó, akadálymentesített gyógyfürdő kiváló és folyamatosan megújuló feltételeket biztosít. Csúcsidőszakban két bejáraton keresztül közelíthető meg a négyféle gyógyvízzel, huszonegy medencével rendelkező létesítmény és a kiegészítő, wellness, fitness és gyógyászati szolgáltatásokat nyújtó központ.

\section{A Szent Erzsébet Mórahalmi Gyógyfüirdő helyi gazdasági fejlődésre gyakorolt hatásai}

A Szt. Erzsébet Gyógyfürdő nagyléptékü fejlesztéseivel egy önmagában is vonzeröt jelentő, a helyi turizmus szervezésének és értékesítésének motorjává váló létesítmény jött létre. A gyógyfürdő működésével összefüggésben jelentkezik annak gazdaságserkentő hatása, aminek alapját az évröl évre emelkedő turistaérkezések adják. Az ennek köszönhető növekvő turistaköltések növelik a helyi vállalkozások és a helyi lakosok jövedelmét, továbbá munkahelyeket generálnak, bövülő foglalkoztatást eredményezve.

A helyi önkormányzat közbenjárásával, valamint a helyi lakosok, vállalkozások és civil szervezetek támogatásával és részvételével, Mórahalom ma már olyan turisztikai attrakciókkal rendelkezik, melyeknek köszönhetően folyamatosan nö a városba érkezö turisták száma, a turistaköltések által a város és lakosainak, illetve a helyi üzleti szféra szereplöinek a jövedelme. Kijelenthetö, hogy a fürdőkomplexum még napjainkban is a felfutási szakaszában van. Évröl évre növekvő müködéséből származó bevételeinek köszönhetően pedig, pénzügyi-gazdasági tekintetben is meghatározó létesítménye, intézménye a kisvárosnak. A 7. ábra a Szt. Erzsébet Mórahalmi Gyógyfürdő helyi gazdaságra gyakorolt hatásait mutatja be vázlatosan. A gyógyfürdő inputokat használ fel a mủködéséhez, ennek eredményként pedig outputokat hoz létre, miközben rövid és hosszú távon egyaránt hatással van a helyi gazdasági életre. Rövidtávon elsősorban a foglalkoztatásra és a jövedelmekre van hatással, hosszú távon pedig a település imázsát, társadalmi tőkéjét, identitását határozza meg. A hatások természetesen kiterjednek a természeti környezetre és a helyi társadalom müködésére is. 


\section{7. ábra: A Szent Erzsébet Gyógyfürdő helyi gazdaságot érintő hatásai}

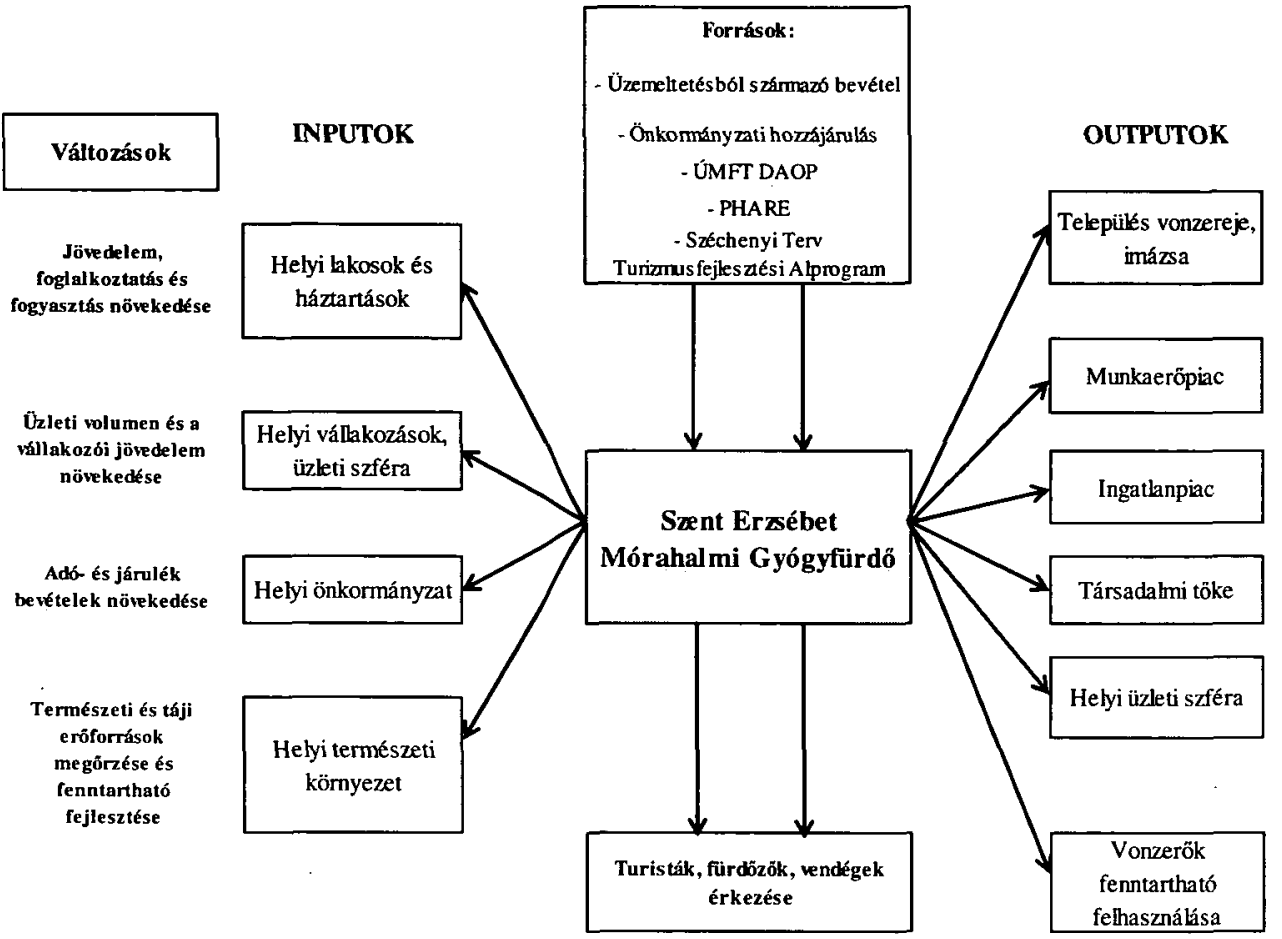

Forrás: Dusek-Lukovics (2014) alapján saját szerkesztés és kiegészítés

A továbbiakban kísérletet teszünk a gyógyfürdő helyi gazdasági hatásainak becslésére. Sajnos nem rendelkezünk konkrét, számszerüsíthető információval az beszállítókról és azok gazdasági teljesítményéről, továbbá nem ismert a bővülö foglalkoztatásból adódó helyben elköltött lakossági jövedelmek nagysága sem, így az indirekt és az indukált hatások becslését nem végezzük el. Ennek megfelelően a következökben a direkt és az indirekt hatások becslésével foglalkozunk.

\subsection{A gyógyfürdő direkt hatásainak becslése}

A gyógyfürdő müködésére vonatkozóan rendelkezünk információkkal, így becsülni tudjuk a müködés miatt létrejövő kibocsátást, a foglalkoztatási és jövedelmi hatást.

A Szt. Erzsébet Mórahalmi Gyógyfürdő az elmúlt évek folyamán országos hírnévre tett szert. A 100\%-ban önkormányzati tulajdonú létesítmény fokozottan figyel a fürdőzök igényeire, a szolgáltatások mennyiségi és minőségi színvonalára, ezért minden évben kisebb-nagyobb bővítéseket, újításokat, fejlesztéseket végeznek a fürdő területén. A fürdöhöz kapcsolódó föbb fejlesztéseket és az általuk realizált fontosabb eredményeket foglalja össze a 8 . ábra. 


\section{8. ábra: A Szent Erzsébet Mórahalmi Gyógyfürdő fejlődésének főbb mérföldkövei}

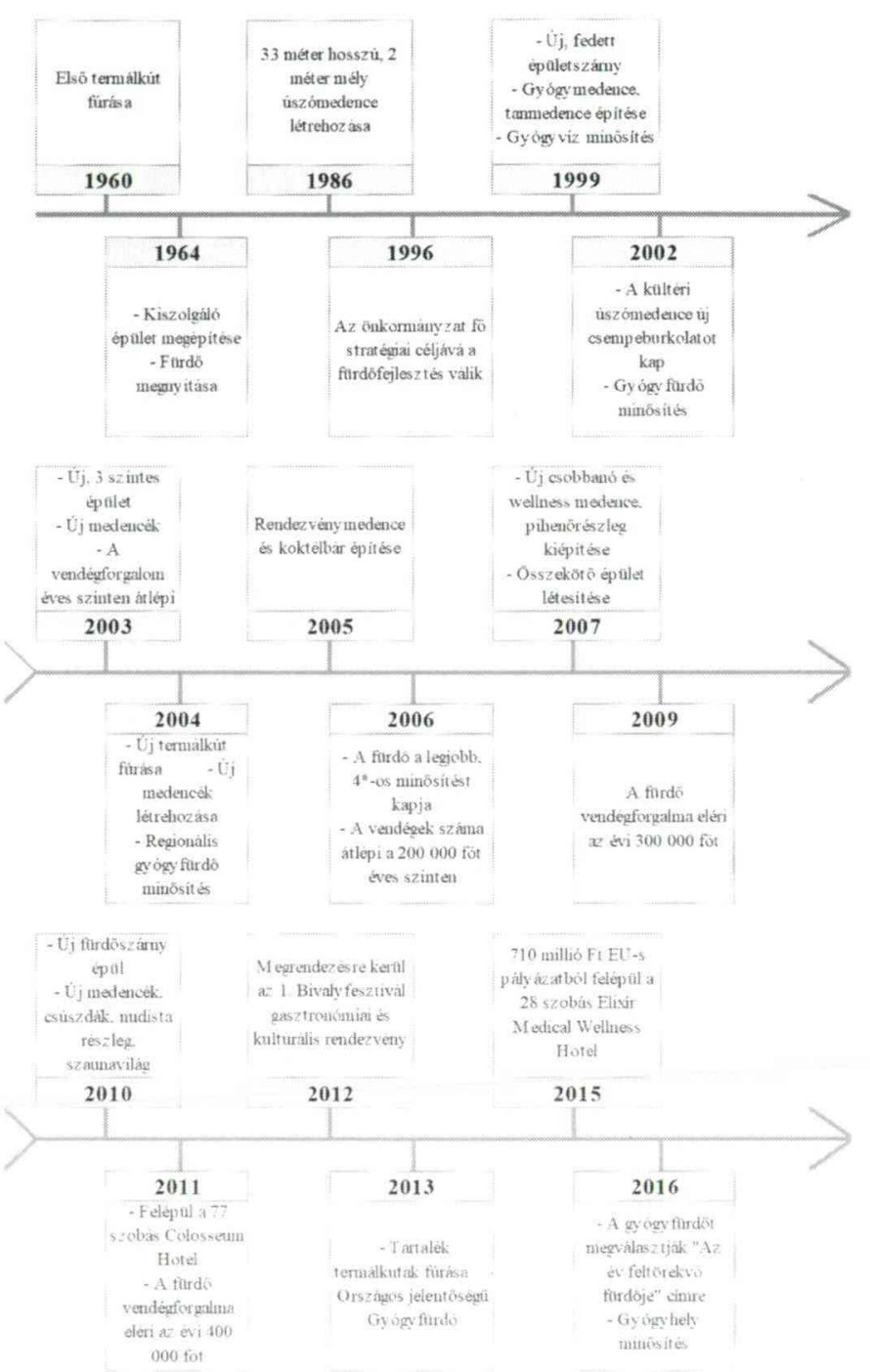

Forrás: Szent Erzsébet Mórahalmi Gyógyfürdő adatai alapján saját szerkesztés

A fürdőkomplexum évről évre rekordszámú látogatóval büszkélkedhet. A fizető vendégek száma 2004-ben 121292 fö volt, ez az érték 2015-ben meghaladta a 453 ezer fös vendégszámot éves szinten (9. ábra). A fürdő a jellegéből adódóan az év nyári hónapjaiban fogadja a legtöbb látogatót, de a szezonalitás csökkentésére és a kedvezőtlen időjárású napokra különböző kedvezményeket hirdetnek, ezek azonban csak kis mértékben tudják ellensúlyozni a nyári csúcsforgalmat. 2015-ben a három nyári hónap (június, július, augusztus) vendégszáma az éves forgalom több mint felét, 51,3\%-át tette ki. 


\section{9. ábra: A Szent Erzsébet Mórahalmi Gyógyfürdő vendégforgalmának alakulása (2002-2015)}

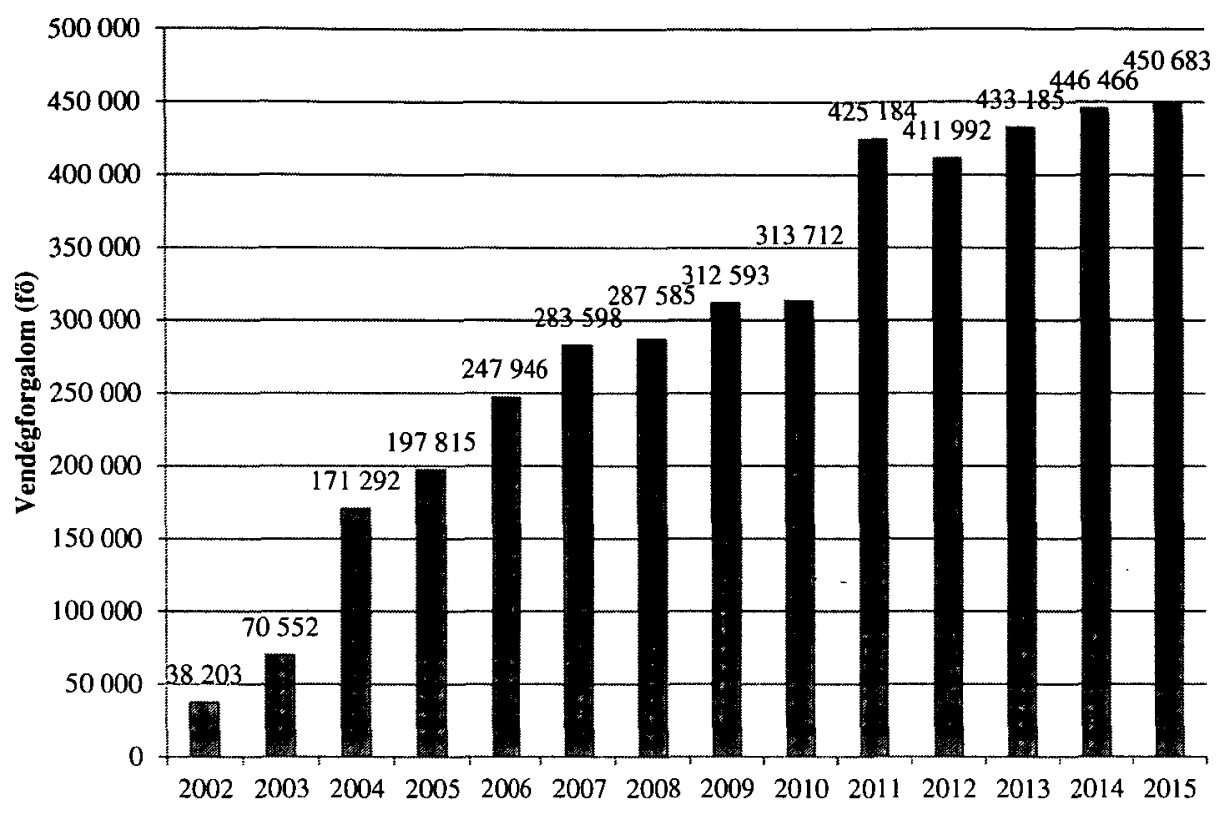

Forrás: Móra-Tourist

A magas vendégszám adatoknak köszönhetően a fürdő jegyárbevétele is évrőlévre rekordokat dönt. Míg a 2004-es adatszolgáltatás során a fürdő közel 64 millió 400 ezer forint bevételt jelentett, addig 2015-ben már több mint 460 millió forintot. A fürdő bevételének meghatározó része jegybevételből származik, de a vásári helypénz, az eszközkölcsönzés, terembérlet és egyéb bevételek is növelik ezt az értéket. A fürdő kiadásait a dologi jellegü ráfordítások határozzák meg, melyek a föszezon elötti fertőtlenítés, nagytakarítás, karbantartás során merülnek fel elsősorban. Emellett a közüzemi számlák (gáz, villamos energia), a személyi jellegü ráfordítások, továbbá a marketingkiadások is jelentős részét képezik a kiadásoknak.

A gyógyfürdő mủködése során, föszezonon kívül 81 fö állandó foglalkoztatását biztosítja, ami a föszezonban további 20-25 fövel, főképp diákokkal bővül. Az alkalmazottak jövedelmének becsléséhez az adminisztratív és szolgáltatást támogató tevékenységet végzők havi bruttó átlagjövedelmét vettük alapul, melynek összege $181338 \mathrm{Ft}$ volt 2014-ben. Ennek megfelelöen a 81 fö állandó alkalmazott havi összjövedelme 14688378 Ft, amely egy évre 176260536 Ft-ot tesz ki. Amennyiben a föszezont júniustól augusztusig tartó időszaknak, azaz három hónapnak tekintem, akkor a 25 fő időszakosan foglalkoztatott személy bruttó összjövedelme, ugyanazon átlagbérrel számolva $4533450 \mathrm{Ft} /$ hó, ami a föszezonra vetítve 13600350 Ft. A Szent Erzsébet Gyógyfürdö által alkalmazottak évi összes bruttó munkajövedelme az elöbbieknek megfelelöen $189860886 \mathrm{Ft}$, ami $124358880 \mathrm{Ft}$ nettó jövedelemnek felel meg. Az előbbieket összevetve a mórahalmi 
lakosok 2014-es SZJA alapot képző összes jövedelmével, ami 4184747790 Ft volt, kimutatható, hogy a gyógyfürdő önmagában az összes mórahalmi bruttó jövedelem 4,5\%-ának megfelelő mértékü elsődleges, munkaviszonyból származó személyi jövedelmet generál. A direkt foglalkoztatási hatás 2331 fó foglalkoztatottal számolva 3,73\%, azaz ekkora részét adja Mórahalom foglalkoztatottságának a gyógyfürdő.

\subsection{A gyógyfürdő katalitikus hatásainak számbavétele}

Előzőekben már foglalkoztunk a vendégforgalom értékelésével és láthattuk, hogy a Mórahalomra érkező turisták száma évröl-évre emelkedik (1. táblázat), ami hatott a szállásadási tevékenység bövülésére ( 6 . ábra) és a vendégéjszakák számának növekedésére (3. ábra). Felhasználva a KSH 2014. január 1-jei adatát, ami szerint az egy vendégre jutó bruttó szállásdíj összege $18136 \mathrm{Ft}$ volt Mórahalmon, becsülhető a szállásadásból származó bevétel nagysága. 2014-ben a településen összesen 76066 vendégéjszakát töltöttek el a turisták, így a település szállásadói megközelítőleg 1380 millió $\mathrm{Ft}$ bevételt realizáltak abban az évben. 90\%-os átlagosnak vett költséghányad mellett a szállásadók mintegy 138 millió forint adózás elötti eredményt értek el.

\section{0. ábra: Mórahalom idegenforgalmi adóbevételének alakulása (1999-2015)}

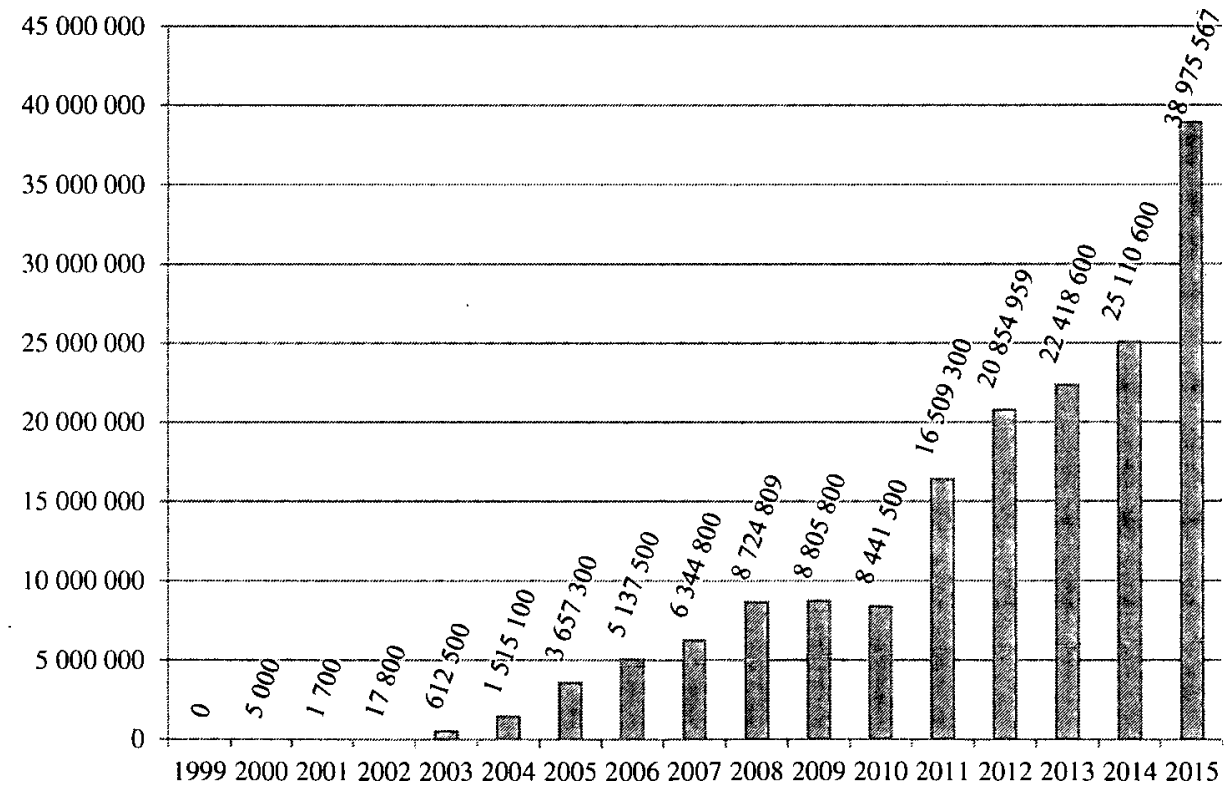

Forrás: Móra-Tourist

$\mathrm{Az}$ utóbbi években az eltöltött vendégéjszakák számának rohamos növekedésével, a kereskedelmi és magánszálláshelyek által az önkormányzat részére fizetendő idegenforgalmi adó (IFA) összege jelentösen emelkedett (10. ábra). Az IFA mint helyi adó az önkormányzat saját bevételeit növeli, ily módon fontos 
szerepe van a település müködésének és fejlesztéseinek finanszírozásában. Mórahalmon 2015 óta minden 18. életévét betöltött, felnött személy után vendégéjszakánként $500 \mathrm{Ft}$ IFA-t kell fizetni, ami a térség legmagasabbjának számít. Általában a hazánk idegenforgalmilag frekventált területein fekvő városok magasabb összegben határozzák meg az idegenforgalmi adó összegét, mint az ilyen szempontból nem érintett települések. Az önkormányzat idegenforgalmi adóbevétele tizenöt év alatt négy nagyságrenddel, közel a nyolcezerszeresére nőtt, ami a vendégéjszakák száma emelkedésén túl az adó mértéke emelkedésének (az 19992002-es időszak $100 \mathrm{Ft} /$ fö/vendégéjszaka érték 2015-re ötszörösére nött) is köszönhetö. 2015-ben az idegenforgalmi adó összege mintegy 0,8\%-át adta a település összbevételének. Az IFA 2015-ös összegének 71,5\%-át a három önkormányzati tulajdonban lévő kereskedelmi szálláshely (Colosseum Hotel, Thermál Panzió, Elixír Hotel) adta. A szállodák, illetve a panzió további szerepét és jelentőségét reprezentálja, hogy összesen 67 főnek adnak munkát, illetve az általuk befizetett iparüzési adó az összes iparüzési adó 10-15\%-át adja, ami a településen müködő egyéb vállalkozások, többek között az ipari parkban müködő nyolcvankilenc vállalkozás befizetéseihez viszonyítva számottevőnek mondható.

A megnövekedett turisztikai keresletet a település a '90-es évek második felében megkezdett szisztematikus fürdőfejlesztések révén érte el. A keresiet bővülésének hatására új piaci lehetőségek nyíltak meg a helyi gazdaság szereplői számára, amit nagyon jól reprezentál a 11 . ábra is, ahol az éttermek, cukrászdák, valamint a vendéglátóegységek (sörözök, borozók, kávéházak, büfék) 2000 és 2014 közötti változása követhető nyomon, érzékeltetve a fürdő müködéséböl és fejlesztéséböl származtatható tovagyürüző hatások egyikét.

\section{1. ábra: A vendéglátóhelyek és az éttermek, cukrászdák számának változása (2000-2014)}

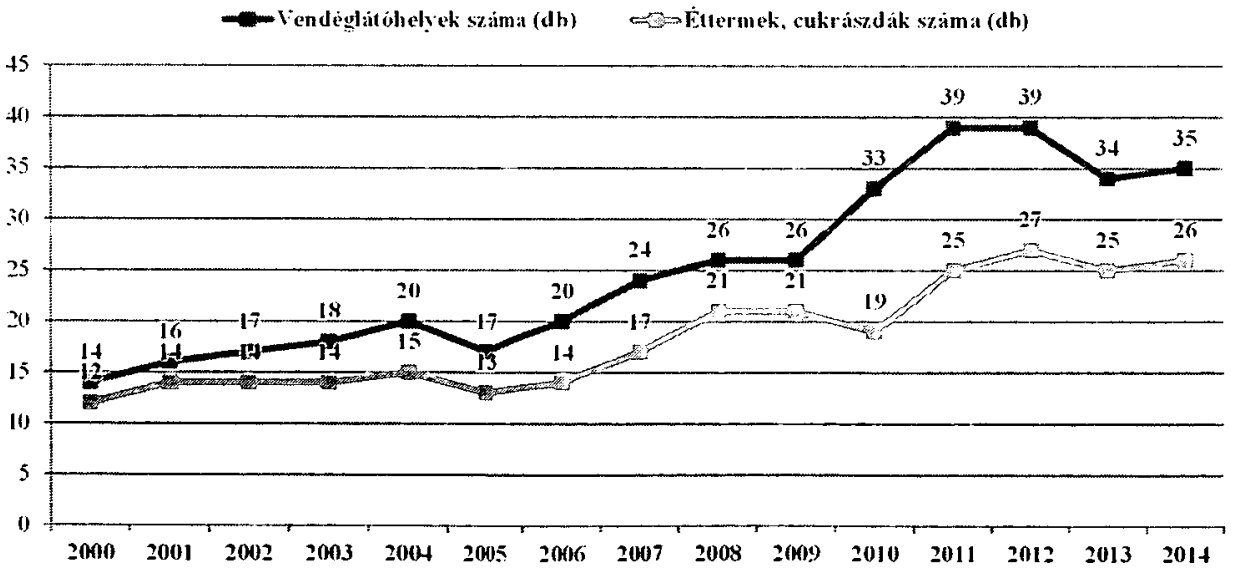

Forrás: TeIR 
A turisztikai kínálat, a turistaérkezések számának bővülésével összefüggésben a helyi vendéglátóhelyek, cukrászdák, éttermek száma a vizsgált tizenöt év alatt a duplájára emelkedett. 2013-ban egy kisebb visszaesés tapasztalható, mely a gazdasági világválság utóhatásának tulajdonítható, de 2014-től ismét növekedés figyelhető meg. A vállalkozók felismerve a turizmusban rejlő potenciált, többnyire a fürdő közvetlen közelében létesítettek telephelyet, vendégeiket elsösorban a fürdőzők adják. Az egy före eső vendégéjszakák számának növekedésével a vendéglátóhelyek, éttermek és cukrászdák bevétele is nőtt, hiszen a turisták elöszeretettel térnek be ezen egységekbe. A forgalmat azon vendégek költései is bővítik, akiknek nem kínál plusz szolgáltatásokat az általa igénybe vett szálláshely, vagy ahol nincs ételkészítési lehetőség.

A katalitikus hatások egyikeként vehetö számba a helyi gazdaság szerkezetére gyakorolt hatás. A gazdaság szerkezetének változását a legutóbbi három népszámlálás adatai alapján a 3. táblázat szemlélteti. A táblázatot megfigyelve több következtetés is levonható. A foglalkoztatottak száma 2001-re lecsökkent, majd 2011-re újra-visszatért az 1990-es szintre. Az első periódusban tapasztalt visszaesés alapvetően a rendszerváltásnak, illetve a nyomában járó általános gazdasági depressziónak tulajdonítható. Az üzemek bezárásával, a munkahelyek megszünésével visszaesett a gazdaság teljesítménye, legfőképp az iparé. Ezzel párhuzamosan a mezőgazdaságban némileg csökkent, a szolgáltatási szektorban pedig jelentősebben bővült a foglalkoztatottak száma, így az előbbi szektorokban foglalkoztatottak aránya öt, illetve hat százalékponttal nőtt. A rendszerváltást követő gazdasági visszaesést hosszú évek megfeszített munkája és a gazdaság modernizációja, szerkezetváltása követte, melynek hatására 2011-ben az 1990-es év szintjére nőtt a foglalkoztatottak száma.

\section{3. táblázat: A gazdasági szerkezet változása a foglalkoztatottak} szektorális eloszlása alapján

\begin{tabular}{|l|r|r|r|}
\hline \multicolumn{1}{|c|}{ Foglalkoztatottak szektoronként } & $\mathbf{1 9 9 0}$ & $\mathbf{2 0 0 1}$ & $\mathbf{2 0 1 1}$ \\
\hline Foglalkoztatottak száma - Ipar, építöipar (fö) & 844 & 491 & 320 \\
\hline Foglalkoztatottak aránya - Ipar, építöipar (\%) & 35 & 25 & 14 \\
\hline Foglalkoztatottak száma - Mezőgazdaság és erdőgazdálkodás (fö) & 565 & 535 & 436 \\
\hline Foglalkoztatottak aránya - Mezőgazdaság és erdőgazdálkodás (\%) & 23 & 28 & 19 \\
\hline Foglalkoztatottak száma - Szolgáltatási jellegú ágazatok (fö) & 197 & 280 & 1375 \\
\hline Foglalkoztatottak aránya - Szolgáltatási jellegü ágazatok (\%) & 8 & 14 & 59 \\
\hline Foglalkoztatottak száma összesen (fő) & 2441 & 1946 & 2331 \\
\hline
\end{tabular}

Forrás: TeIR

A táblázatból az is tökéletesen kirajzolódik, hogy 2011-re az ipar, építöipar gazdasági szektor és a mezőgazdasági szektor jelentősége, az alkalmazottak 
számának és arányának változása alapján, a szolgáltatás jellegủ szektorral szemben visszaesett. 1990-ben az ipari szektoré volt a meghatározó szerep, hiszen a foglalkoztatottak 35\%-át ezen gazdasági szektor foglalkoztatta, ám ennek értéke 2011-re 14\%-ra csökkent. A szolgáltató szektor felé való elmozdulás az alkalmazottak számának növekedése alapján vitathatatlan. Napjainkban közel hétszer annyi ezen szektor foglalkoztatottainak száma, mint 1990-ben. Ez többek között a mezőgazdaság gépesítettségének, a munkatermelékenység növekedésének, a '90-es éveket követő Szegedről történő kitelepüléseknek, továbbá a helyi gazdaság fejlődésének, szerkezetátalakulásának tudható be, amiben fontos szerepet játszott a fürdőfejlesztés és a turizmus fejlődése is.

További fontos katalitikus hatásként jelenik meg a település arculatának, imázsának változása. Mórahalom igen jelentős változáson, fejlődésen ment keresztül az elmúlt másfél-két évtizedben, ami megannyi dologban testet ölt, gondoljunk csak a beruházások és fejlesztések eredményezte infrastrukturális változásokra, a településkép, a tevékenységek, a foglalkoztatás, a helyiek attitüdjének stb. megváltozására. Egy új identitás létrehozásának/létrejöttének jelei fedezhetők fel az gyógyfürdő által szervezett rendezvények témáit illetően is, amelyek beépültek a település mindennapjaiba és marketingjébe. Egyrészt arról van szó, hogy a településen élök minél inkább azonosuljanak a környezetükben lévő értékekkel, ezek turisztikai hasznosításával, elfogadják, illetve magukénak tudják ezeket az új tevékenységeket és az elért eredményeket, ami által elkötelezödnek az új irány mellett, így teremtve meg az alapot a további fejlödéshez. Másrészt nagyon fontos a kifelé irányuló kommunikáció, a település, illetve a hozzá kapcsolódó turisztikai termék(ek), a település, a desztináció értékesítésének elömozdítása, amelyben a vonzerők és az azokra épülő szolgáltatások egyediségének, minőségének közvetítése kiemelkedő jelentőségü. Így jelentek meg például olyan szlogenek mint a „Mórahalom a gyógyvizek városa”, a „Mártózzon meg az egészségben karnyújtásnyira Szegedtől!” vagy az „Üdülés Mórahalmon! Nálunk mindent megtalál.". Ezek a jelmondatok és egyéb marketingeszközök nagyban hozzájárulnak a vonzerő, a termék és a település egyediségének és egymáshoz való kapcsolásának kommunikációjához, ami már fürdő nevében is kifejezésre kerül.

Mára Mórahalom ismertsége és gazdasága leginkább a turizmuson, azon belül is a Szent Erzsébet Mórahalmi Gyógyfürdő vonzerején és a rá épülő turisztikai szolgáltatásokon alapul. Ezt jól reprezentálja, hogy míg az ezredfordulót követő első évtizedben a település neve és ismertsége a Mórakert Szövetkezethez, Magyarország első elismert termelő értékesítő szervezetéhez kapcsolódott, ma pedig fürdőjéröl a Szent Erzsébet Mórahalmi Gyógyfürdőről ismert és elismert a település. Persze az igazsághoz hozzátartozik, hogy többünk sajnálatára a TÉSZ ma már nem létezik, 2011-ben felszámolási eljárásba vonták, nem állta ki az idő, azaz a piac próbáját, miközben a gyógyfürdő és az arra épülő turizmus a '90-es évek második felében elkezdett tudatos és szisztematikus turizmusfejlesztés eredményeként továbbra is emelkedő pályán mozog.

A vonzerőfejlesztés, a turisztikai forgalom bővítése a fürdőfejlesztésen túl megköveteli a marketingtevékenység folyamatos fejlesztését is. A turisztikai értékek 
bemutatására és kommunikációjára igénybe vett marketingeszközöket a 12 ábra szemlélteti.

\section{2. ábra: A gyógyfürdő által igénybe vett marketingeszközök csoportosítása}

$\begin{array}{cl} & \text { - szórólapok, prospektusok } \\ \text { Materiális } & \text { - plakátok, poszterek } \\ \text { marketing } & \text { - helyi és megyei újságok, újsághirdetések } \\ \text { eszközök } & \text { - kedvezményes belépök (véradóknak, egyéb } \\ & \text { szálláshelyen megszállóknak) } \\ & \text { - kitelepülések, kiállítások } \\ & \text { - tömegközelekedési reklámfelületek }\end{array}$

$\begin{array}{cl}\text { Nem } & \text { - rendezvények, fesztiválok } \\ \text { materiális } & \text { - rádió, TV hirdetés, reklâmfilm } \\ \text { marketing } & \text { - weboldal } \\ \text { eszközök } & \text { - hírlevelezés } \\ & \text { - közösségi oldalakon való megjelenés } \\ & \text { - élő webkamera adás }\end{array}$

Forrás: Móra-Tourist

A Szent Erzsébet Mórahalmi Gyógyfürdő mottója: „Az egészség és a családok szolgálatában". A három generációra kiterjedő létesítményben a fürdő elsődleges célcsoportjai, az egészségügyi problémákkal küzdő idősebb korosztály, a fiatal házaspárok gyerekekkel és az egészségtudatos, szórakozni vágyó fiatalok, akik aktív részesei lehetnek az komplexum területén található élményelemeknek, szolgáltatásoknak. Az egyre növekvő számú, vonzó kínálattal rendelkező desztinációk versenyében csak jól meghatározott egyedi kínálati elemekkel és megfelelö marketingeszközökkel lehet a megcélzott célcsoportokat megnyerni. Mórahalom egy komplex, belföldi és külföldi viszonylatban is versenyképes egészségturisztikai kínálattal jelenik meg a turisztikai piacon, amelynek föbb jellemvonásai a minöség és a megfelelö árpolitika. Az elmúlt években a kisváros egy jól működő sikeres marketing tevékenységet vitt véghez, amit a fürdő vendégforgalmának nagyarányú emelkedése is jól reprezentál, miközben a környéken több gyógy- és wellness létesítmény is üzemel. A fürdő müködését folyamatos, aktív marketingmunka segíti a helyi TDM szervezet részéröl, ami a város és a kistérség propagálását is magába foglalja. $\mathrm{Az}$ ismertetett marketingeszközök közül az utóbbi években a közösségi médiafelületeken való megjelenés jutott nagyobb szerephez, mivel ott több embert lehet megszólítani és belföldihez, külföldihez egyaránt gyorsan eljuttatható az információ. Ezeken az interfészeken a fürdő, a város és a kistérség eseményei, akciói napi szinten megosztásra kerülnek. A közösségi oldalak használata nemcsak az információk 
megosztását teszi lehetővé, hanem lehetőséget ad a visszajelzésekre és véleményalkotásra is. A Google felületén történő osztályozáson túl a látogatók a létesítmény saját Facebook oldalán is tudják értékelni a tapasztalatokat. Jelenleg a Facebookon voksolók átlagban 4,68-ra értékelik a mórahalmi gyógyfürdőt.

Egy másik, költségesebb felhasznált marketingeszköz az éves szinten frissített, Mórahalom és a Mórahalmi kistérség eseményeit tartalmazó Rendezvénynaptár, melyet a Móra-Tourist Nonprofit Kft. munkatársai készítenek el. Ezekben a prospektusokban hónapokra bontva szerepelnek külön-külön a városban és a környék településein megrendezésre kerülő rendezvények. A kiadványokat a fürdő területén, a Tourinform Irodában és a környező településeken szórják szét.

A helyi TDM szervezet képviselői föként a magyarországi kiállításokon és vásárokon keresztül népszerüsítik a települést, de szerb és román rendezvényeken is elöszeretettel vesznek részt. Továbbá a Magyar Turisztikai Ügynökségen keresztül Ausztriába, Szlovákiába és Lengyelországba is eljut a mórahalmi gyógyfürdő híre.

A település naponta frissülö, önálló honlapja (www.morahalom.hu) a turizmusnak, a turisztikai kínálat reklámozásának külön fejezetet szentel. A vonzerök és a rendezvények ismertetésén túl, segítséget kaphatunk a szálláskeresésben, szállásfoglalásban és egy körpanoráma segítségével bejárhatjuk Mórahalom nevezetességeit is. A gyógyfürdő sokrétü, informatív honlapján keresztül (www.erzsebetfurdo.morahalom.hu) minden szükséges információt megkaphatunk az utazáshoz (megközelíthetőség, árakra, szolgáltatások, nyitva tartás stb.). A fürdő vezetősége a „Kapcsolat” fül alatt található online vendégkönyvön keresztül fogadja a látogatói bejegyzéseket. Ide többnyire pozitív hozzászólások érkeznek, de néha az is elöfordul, hogy a vendégek a nemtetszésüket fejezik ki. A vendégkönyv bejegyzésein túl a fürdő munkatársai különböző mérésekkel próbálják megismerni még jobban a látogatók véleményét. A fürdőben rendszeresen küldöterület felmérés folyik, mely során azokat a területeket összegzik, ahonnan a legtöbb vendég érkezik. Ennek a kutatásnak az eredményeit elsősorban az online marketing megtervezésekor használják fel, hiszen a Facebookon, és az egyéb online felületeken megjelenő reklámok esetében beállítható, hogy mely országrészben, milyen mértékben, gyakorisággal jelenjenek meg a hirdetések.

Mórahalom városa és a Szent Erzsébet Mórahalmi Gyógyfürdő közel tíz éve támogatja a helyi spotközösségen túl a véradókat is. A Nógrádi Zoltán polgármester által elöször 2006-ban kezdeményezett akció során eddig több százezer kedvezményes árú fürdőbelépő került kiosztásra. Az akció sikerét jól fémjelzi, hogy az elmúlt években több más fürdő is átvette ezt a fajta kezdeményezést. Azonban nem csak a véradók juthatnak kedvezményes árú fürdöbelépöhöz, hanem az egyes magánszálláshelyek vendégei is. $\mathrm{Az}$ akció lényege, hogy az erzsebetfurdo.morahalom.hu, illetve a morahalomturisztika.hu honlapokon megtalálható mórahalmi magánszálláshelyeken megszálló vendégek, személyenként annyi ötszáz forintos kedvezményes fürdöbelépöt kapnak, ahány vendégéjszakát töltenek az akcióban részt vevő szálláshelyeken. Ez a kezdeményezés fellendíti az akcióban résztvevő a magánszállásadók forgalmát, melynek tovagyürüző hatásából fuirdő és város egyaránt profitál. 


\section{A fürdőfejlesztés vállalkozásokra gyakorolt hatásainak értékelése a kérdőíves felmérés tükrében}

A következőkben kérdőíves felmérésünk eredményeit ismertetjük röviden. A felmérésben 10 magánszállásadó és 18 vállalkozás (éttermek, büfék, egyéb kiskereskedelmi egységek: pékség, ruházati bolt, ékszerbolt) vett részt. A kismintás, nem reprezentatív felmérésünkbe a fürdőben és annak közvetlen környezetében elhelyezkedő gazdasági szereplőket vontunk be annak érdekében, hogy valós információkat kapjunk arról, hogy a gyógyfürdő működése, fejlesztése és az általa gerjesztett növekvő látogató és turistaforgalom milyen szerepet játszott/játszik a vállalkozások müködésében (alapítás, átszervezés, fejlesztés, jövőbeni tervek, árbevétel, nyereség, foglalkoztatás).

A vállalkozások létrehozása, alapítása 1995 és 2016 között történt, elsősorban az ezredfordulót követően. A tizennyolc vállalkozás közül tizenötöt valódi új vállalkozásként hoztak létre, három máshonnan költözött oda, egy Szegedröl, kettő pedig a város távolabbi pontjáról; olyan esetre nem derült fény, amely során a már meglévő telephely mellett nyitott volna új üzletet a tulajdonos.

A kutatás során arra kértük a tulajdonosokat, hogy egy 1-től 5-ig terjedő skálán értékeljék, hogy a vállalkozás alapításában mekkora szerepet játszott a fürdőfejlesztés és a turistaérkezések bővülése (1=egyáltalán nem volt hatással, $5=$ teljes mértékben befolyásolta). A válaszok alapján egyértelmủ, hogy legtöbbjük a fürdő kapcsán hozta létre, illetve indította el tevékenységét. A 13. ábra adatai és a vállalat alapításának éve között az az összefüggés is megfigyelhető, hogy minél később hozták létre a vállalkozást, annál nagyobb szerepet játszott alapításában a fürdőfejlesztés és a vendégforgalom bővülése.

\section{3. ábra: A fürdőfejlesztések hatása a vállalkozások alapítására, bővítésére}

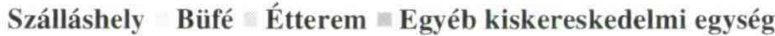

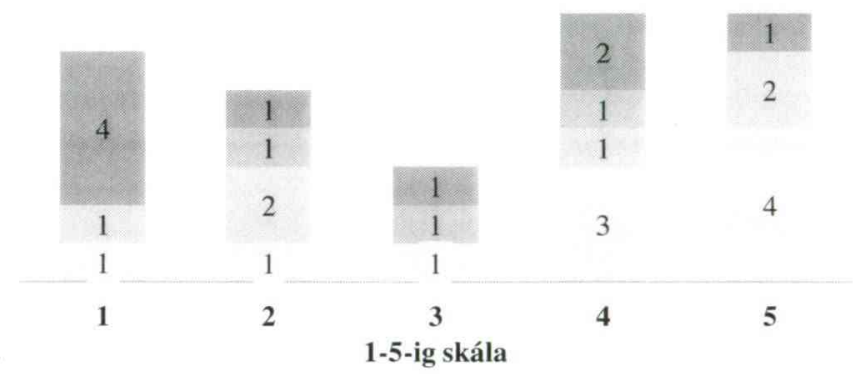

Megjegyzés: Az ábrában található számok a válaszadók számát jelölik

Forrás: Kérdöíves felmérés alapján saját szerkesztés

A szálláshelyek számának bővülése, minőségi javulása, az eltöltött vendégéjszakák magas száma a sikeres müködést fémjelzi, ezért az utóbbi években egyre több lakos állt a turizmus szolgálatába házának, lakásának, kihasználatlan lakóhelyiségeinek kiadásával. A tíz megkérdezett szálláshelyadónál az új 
versenytársak megjelenése azonban nem éreztette hatását, hiszen árbevétel- és jövedelemnövekedésről számoltak be az elmúlt öt év tekintetében. A magánszállásadók esetén bekövetkezett változásokat és azok irányait a 14 . ábra szemlélteti.

\section{4. ábra: A magánszállásadásban bekövetkezett változások és azok irányai 2011-tôl napjainkig}

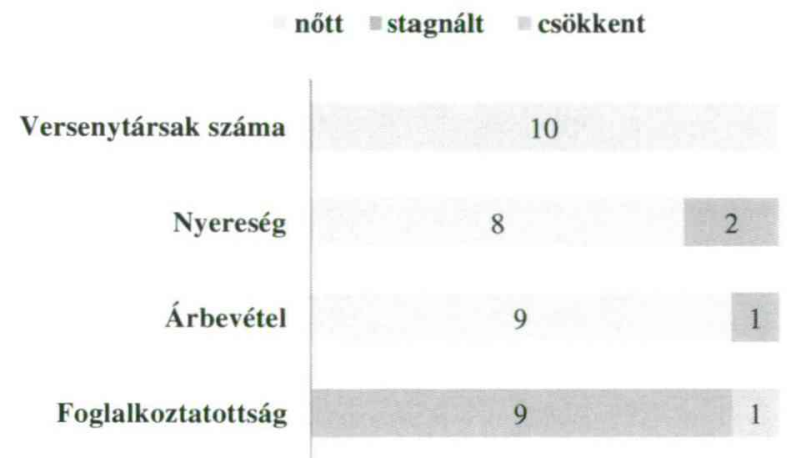

Megjegyzés: Az ábrában található számok a válaszadók számát jelölik

Forrás: Kérdöíves felmérés alapján saját szerkesztés

Az ábrából jól kivehető, hogy a megkérdezettek 80-90\%-a árbevétel- és jövedelemnövekedésröl számolt be. Ennek mértékét átlagosan 10-20\%-ra becsülték, de volt olyan is, aki 50\%-os növekedésről számolt be. A magasabb értékeket közlők a minőségi színvonal emelésével és a kapacitásbővítéssel magyarázták a vendégszám emelkedését. A versenytársak számának gyarapodása minden válaszadó számára egyértelmű volt, de a növekedés mértékének becslésében nagyarányú eltérések mutatkoztak. Egyes megkérdezettek szerint öt év alatt 5\%-kal nőtt csak a konkurencia, míg mások úgy vélték, hogy ötször annyi a versenytárs, mint 2011-ben.

Kutatásunk a szállásadókon túl a fürdő köré települt és a fürdőben üzemelö büfékre, éttermekre és egyéb kiskereskedelmi egységekre (ruházati bolt, ékszerbolt, pékség) is kiterjedt, ahol szintén a foglalkoztatottság, az árbevétel, a jövedelem és a versenytársak számának változását vizsgáltuk (15., 16. és a 17. ábra).

A hat felkeresett büfé közül négy számolt be árbevétel- és jövedelemcsökkenésröl, stagnálásról, sőt, egy vállalkozás a bezárást fontolgatja ( 15 . ábra). Ez azért igen érdekes, mert a hat büfé közül négy a fürdő területén müködik. A büfék rossz eredménye többek között annak tulajdonítható, hogy a fürdő vendégkörének többsége otthonról viszi az elfogyasztani kívánt ételt és italt a fürdő területére, melynek okát elsősorban a magas árak, a szük kínálat és a hosszú sorbanállási idő magyarázza. A vizsgálat során a csökkenő jövedelmet tapasztalók 20-30\%-ra becsülték a visszaesést, míg a két eredményes vállalkozás 10-15\%-os nyereségemelkedésről számolt be. A fürdő területén üzemelő, jövedelemcsökkenést jelentő vállalkozások arra panaszkodtak, hogy a növekvő igényekkel párhuzamosan 
bővíteni kívánták telephelyüket, kínálatukat, de a szükös helyi adottságok miatt erre nem volt lehetőségük, így elmaradtak versenytársaikkal szemben.

15. ábra: A büfék múködése során bekövetkezett változások és azok irányai 2011-től napjainkig

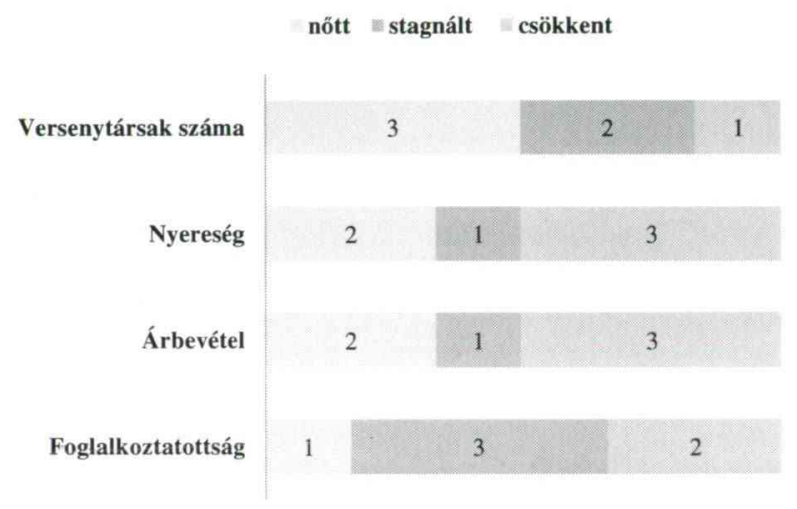

Megjegyzés: Az ábrában található számok a válaszadók számát jelölik

Forrás: Kérdőíves felmérés alapján saját szerkesztés

16. ábra: Az éttermek múködése során bekövetkezett változások és azok irányai 2011-től napjainkig

$$
\text { nôtt stagnált }
$$

Versenytársak száma

Nyereség

Árbevétel

Foglalkoztatottság

Megjegyzés: Az ábrában található számok a válaszadók számát jelölik

Forrás: Kérdőíves felmérés alapján saját szerkesztés
1

1
3 


\section{7. ábra: Az egyéb kereskedelmi egységek müködése során bekövetkezett változások és azok irányai 2011-től napjainkig}

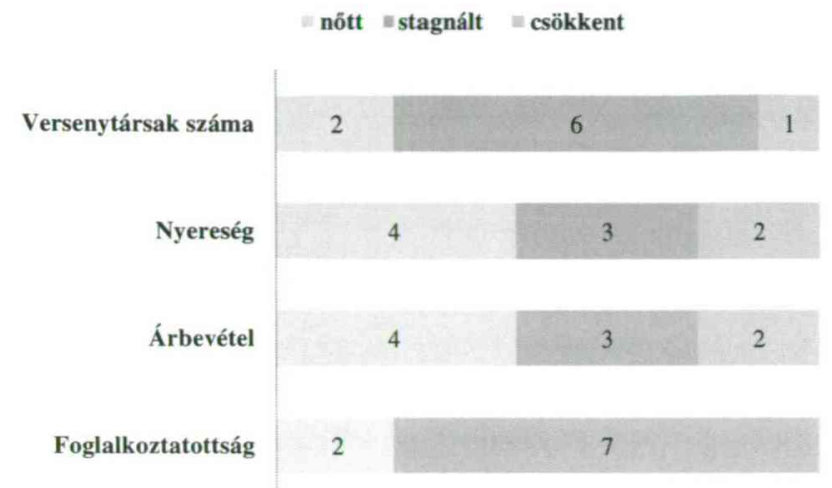

Megjegyzés: Az ábrában található számok a válaszadók számát jelölik Forrás: Kérdőíves felmérés alapján saját szerkesztés

A 16. ábra adatai három, hotelen kívül üzemeltetett éttermet foglal magába. A fürdővendégek, turisták és az egy főre jutó vendégéjszakák számának növekedésével párhuzamosan az éttermek forgalma is érezhetően emelkedő tendenciát vett az utóbbi időben, ami által az árbevételük is nőtt. A forgalomnövekedés intenzitása elsősorban a délutáni, esti órákban figyelhető meg, miután a vendégek elhagyják a fürdő területét. A felmérés során a vállalkozók átlagosan 30-40\%-os jövedelemnövekedésről számoltak be, ami annak fényében, hogy 2010-ben a Colosseum Hotelben, 2015-ben pedig az Elixír Hotelban nyílt étterem, lenyügözö eredmény. A forgalombövülésnek köszönhetően mindhárom étterem esetén szükségessé vált új alkalmazottak felvétele. A vizsgált éttermek esetében kettő, három és öt fövel bővült az alkalmazottak köre.

A 17. ábrán az egyéb kiskereskedelmi egységek (ékszerbolt, ruházati bolt, pékség) múködése során bekövetkezett változásokat szemléltetjük. Az ábra ugyan vegyes képet mutat a nyereség, az árbevétel és a versenytársak tekintetében, de ha típusonként megkülönböztetjük az üzleteket, akkor megfigyelhető, hogy azon egységek számoltak be nyereségről és a foglalkoztatottak számának bővüléséről, melyekbe a helyi lakosságon túl a városba érkező turisták is betérnek. Ilyen a pékség, az ajándékbolt és az ékszerbolt. A kínai és a használt ruhaboltok tulajdonosai eredményük és forgalmuk csökkenésének okait azzal magyarázták, hogy a turisták csak végső esetben térnek be hozzájuk, tehát ha valami otthon maradt vagy tönkrement az üdülés alatt.

A kiskereskedelmi egységek között sikeresen múködő vállalkozások 10-15\%os árbevétel-növekedésről és a foglalkoztatotti létszám 2-3 fövel történő bővítéséröl, a ruházati boltok pedig kb. 40\%-os árbevétel-csökkenésről és egy-két alkalmazott elbocsátásáról számoltak be az elmúlt öt év tekintetében.

A kutatásban résztvevő vállalkozások jelentős része a folyamatosan változó igényekre és a növekvő keresletre helyiség- és telephelybővítéssel, fejlesztéssel, 
illetve a tevékenységi, szolgáltatási kör kiszélesítésével reagált. Gondolhatunk itt olyan szolgáltatásokra, melyek korábban a településen nem voltak elérhetőek, vagy például a szálláshely szórakoztatóelektronikai ellátására.

A folyamatos erőfeszítés és fejlesztés, a turisták igényeinek minél magasabb szinten történő folyamatos kielégítése a turizmusban sikeres település kulcsa. Éppen ezért rendkívül fontos, hogy ne csak a város fỏ attrakciójában, hanem az azt kiszolgáló, kiegészítő és támogató egységekben is megvalósuljanak ezek a folyamatok. A vizsgálatban résztvevő huszonnyolc vállalkozás jövőbeni terveinek feltérképezése során megállapítást nyert, hogy mindössze nyolc üzlet, illetve szálláshely kíván bövíteni, fejleszteni a közeljövöben. Többnyire a tevékenységi kör bővítése a cél, amelynek során például valamely szállásadó biciklikölcsönző, más kisállatsimogató kialakítását tervezi. A válaszadók nyilatkozataiból megállapítható, hogy ezen fejlesztések létrehozásában mintegy 50\%-ban játszik szerepet a fürdőfejlesztés és a fürdő vendégforgalmának növekedése.

\section{Záró gondolatok}

Mórahalom turisztikai vonzereje alapvetöen a gyógyfürdöre épül, ami az elmúlt másfél-két évtizedben a helyi fejlesztések alapjává vált. A megvalósított és folytatódó fejlesztések eredményeként a település olyan turisztikai értékajánlatot tud nyújtani a közönség számára, amely jelentős, évente növekvő mértékü turistaforgalmat generál, ami újabb munkahelyek létrejöttét és pótlólagos jövedelmeket eredményez a helyi gazdaságban. Mára Mórahalom ismertsége és gazdasága leginkább a turizmuson, azon belïl is a Szent Erzsébet Mórahalmi Gyógyfürdő vonzerején és a rá épülő turisztikai szolgáltatásokon alapul, amelyek a számszerüsíthető gazdasági hatásokon túl, befolyásolják a településen élők identitását, gondolkodását és alapvetően határozzák meg a városról kialakult képet. Hogy mit hoz a jövő nem tudható, annyi biztos, hogy a változó igények és piaci trendek megkövetelik a további fejlesztéseket. Ezen fejlesztések kulcstényezője a társadalmi, gazdasági és környezeti szempontok érvényesítése, illetve a helyi identitás, a helyi kultúra megőrzése, mivel csak így biztosítható az adottságok és erőforrások helyi értékek és érdekek mentén történö fenntartható hasznosítása, amelynek révén lehetővé válik az egyediség megörzése és a gazdasági kontroll helyben tartása.

\section{Irodalomjegyzék}

Aubert A. (2001): A turizmus és a területfejlesztés stratégiai kapcsolata Magyarországon. Turizmus Bulletin, 5 (1): 44-49.

Aubert A. (2002): A turizmus földrajza. In: Tóth J (szerk.): Általános társadalomföldrajz II. (Dialóg Campus Tankönyvek) Dialóg Campus Kiadó, Budapest-Pécs. 143-160.

Aubert A. (2011): Turisztikai régiók helyzete a területfejlesztésben. In: Dávid L. (szerk.): Magyarország turisztikai régiói. Pécsi Tudományegyetem, Pécs. $<$ http://www.eturizmus.pte.hu/szakmaianyagok/Magyarorsz\%C3\%A1 g\%20idegenforgalmi\%20r\%C3\%A9gi\%C3\%B3i/book.html\#d6 e1094>. (2017.03.10.)

Bajmócy Z. (2011): Bevezetés a helyi gazdaságfejlesztésbe. JATEPress, Szeged. 
Belényi Gy. (1992): Politika, gazdaság, társadalom 1950 és 1970 között. In: Juhász A. (szerk.): Mórahalom. A település fóldje és népe. Mórahalom Város Önkormányzata, Mórahalom. (Elektronikus megjelenítés: NKÖEOK Szerkesztőség - 2007) <http://web.morahalom.hu/sajto/a_telepules_foldje_es_nepe/heraldicart.uw.hu/Morahalom/pag es/009_politika_gazdasag.html>. (2017.03.03.)

Duró A. (1992): Társadalomföldrajzi vizsgálatok a mórahalmi tanyavilágban. In: Juhász A. (szerk.): Mórahalom. A telepuilés földje és népe. Mórahalom Város Önkormányzata, Mórahalom. (Elektronikus megjelenítés: NKÖEOK Szerkesztöség - 2007) <http://web.morahalom.hu/sajto/a_telepules_foldje_es_nepe/heraldicart.uw.hu/Morahalom/pag es/010_tarsadalomfoldrajzi.html>. (2017.03.03.)

Dusek T., Lukovics M. (2014): Az ELI és az ELI Science Park gazdasági hatásvizsgálata. Területi Statisztika, 54 (3), 202-219.

G. Tóth I. (1992): Szeged-Alsótanyától Mórahalomig. In: Juhász A. (szerk.): Mórahalom. A telepuilés földje és népe. Mórahalom Város Önkormányzata, Mórahalom. (Elektronikus megjelenítés: NKÖEOK Szerkesztöség <http://web.morahalom.hu/sajto/a_telepules_foldje_es_nepe/heraldicart.uw.hu/Morahalom/pag es/005_szeged_alsotanyatol.html>. (2017.03.03.)

Gál J. (1999): Az alföldi régió néhány környezetvédelmi, társadalmi-gazdasági összefüggése. In: Baukó T. (szerk.): Az Alfôld a XXI. század küszöbén. Nagyalföld Alapítvány, Békéscsaba. 375378.

Hustiné Béres K. (2011): Fürdők és az egészségturizmus közgazdaságtana. Szent István Egyetem, Gödöllö. <http://www.tankonyvtar.hu/hu/tartalom/tamop412A/20100019_Furdok_es_az_egeszsegturizmus_kozgazdasagtana/index.html>. (2016.05.19.)

IPU (Inter-Parliamentary Union), WTO (World Tourism Organization) (1989): The Hague Declaration on Tourism. unwto.org/doi/pdf/10.18111/unwtodeclarations.1989.15.4.1>. (2017.04.29.)

ITS: ITS DA Konzorcium (2015): Mórahalom Város Integrált Településfejlesztési Stratégiája, Mórahalom.

$<$ http://web.morahalom.hu/sajto/a_telepules_foldje_es_nepe/heraldicart.uw.hu/Morahalom/pag es/009_politika_gazdasag.html>. (2016.06.24.)

Juhász A. (1992): Bevezetés. In: Juhász A. (szerk.): Mórahalom. A település fóldje és népe. Mórahalom Város Önkormányzata, Mórahalom. (Elektronikus megjelenítés: NKÖEOK Szerkesztöség

$<$ http://web.morahalom.hu/sajto/a_telepules_foldje_es_nepe/heraldicart.uw.hu/Morahalom/pag es/002_bevezetes.html>. (2017.03.03.)

Kassai, Zs., Gergely, A., Szabó, Z. (2009): The Plum Tour of Szabolcs-Szatmár-Bereg. In: Káposzta, J. (ed.): New elements and research in spatial economy. Research Institute of J. Selye University, Komárom. 50-59.

Kis K. (2014): Vidékgazdaság, kultúra, lokalizáció: eltérỏ válaszok és fejlödési differenciák. Jelenkori Társadalmi és Gazdasági Folyamatok, 9 (1-2): 9-28.

Kis K., Pesti K. (2015): Szegedi élelmiszeripari hungarikumok helyzete, lehetőségei a globalizáció és a lokalizáció kölcsönhatásában: eredet, hagyomány és minőség szögediesen. Jelenkori Társadalmi és Gazdasági Folyamatok, 10 (2): 9-34.

Kis K., Tóth A. (2016): Az ökoturizmus helyi rendszerének vizsgálata Poroszlón, különös tekintettel a Tisza-tavi Ökocentrum helyi gazdaságfejlesztési szerepének értékelésére. Északmagyarországi Stratégiai Füzetek, 13 (1): 73-91.

Kulcsár D. (2013): Turizmusföldrajz. In: Jeney L., Kulcsár D., Tózsa I. (szerk.): Gazdaságfóldrajzi tanulmányok közgazdászoknak. BCE Gazdaságföldrajz és Jövőkutatás Tanszék, Budapest. 153173.

Lengyel I., Rechnitzer J. (2004): Regionális gazdaságtan. Dialóg Campus Kiadó, Budapest-Pécs.

Lengyel M. (1997): Ökoturizmus és marketing. MTA stratégiai kutatások, Budapest.

Lengyel M. (2008): TDM Müködési Kézikönyv. Heller Farkas Gazdasági és Turisztikai Szolgáltatások Föiskolája, Budapest. 
Martyin Z., Boros L. (2012): A turizmus szerepe Mórahalom fejlödésében. Közép-Európai Közlemények, 5 (2): 145-158.

Michalkó G. (2004): A turizmuselmélet alapjai. Kodolányi János Föiskola, Székesfehérvár.

Michalkó G. (2005): A Tisza-tó turisztikai potenciálja. Földrajzi Értesítõ, 54 (1-2): 129-147.

Michalkó G. (2011): A turisztikai termék. In: Michalkó G. (szerk.): Turisztikai terméktervezés és fejlesztés. Pécsi Tudományegyetem, Pécs. <http://www.tankonyvtar.hu/hu/tartalom/tamop425/0051_Turisztikai_termektervezes_es_fejles ztes/ch01.html>. (2016.04.18.)

Nagy S. (2014): Stratégiai esettanulmányok. In: Gulyás L. (szerk.): Stratégiai menedzsment Szun-Cetól a kék óceánig. JATEPress, Szeged. 137-188.

Oláh J. (2002): Az idegenforgalom fejlesztésének lehetőségei a Nagykállói statisztiaki körzetben. Acta Agraria Debreceniensis - Agrártudományi Közlemények, 2002/Különszám: 86-87.

Oláh, J. (2014): The problem of the typologization of rural regions in Europe. Euroregional Journal of Socio-Economic Analysis, 2 (1): 17-28.

Perczel Gy.(2003): Idegenforgalom. In: Prczel Gy. (szerk.): Magyarország társadalmi-gazdasági fóldrajza. ELTE Eötvös Kiadó, Budapest. 436-454.

Raffay, Z., Jónás-Berki, M., Aubert, A., Marton, G. (2013): Local tourism destination management organisations - some first experiences of Hungary. Vestnik Karagandinskogo gosudarstvennogo universiteta Seriya: Ekonomika, 71 (3): 105-109.

Sheffer K. (1992): Településtörténet. In: Juhász A. (szerk.): Mórahalom. A település földje és népe. Mórahalom Város Önkormányzata, Mórahalom. (Elektronikus megjelenítés: NKÖEOK Szerkesztőség

<http://web.morahalom.hu/sajto/a_telepules_foldje_es_nepe/heraldicart.uw.hu/Morahalom/pag es/004_telepulestortenet.html>. (2017.03.03.)

Székely A. (2013): Regionális multiplikáció a szegedi Árkád példáján. In: Rechnitzer J., Somlyódyné P. E., Kovács G. (szerk.): A hely szelleme - a területi fejlesztések lokális dimenziói: A Fiatal Regionalisták VIII. Konferenciáján elhangzott elöadások. Széchenyi István Egyetem RGDI, Györ. 565-573.

UNWTO (World Tourism Organization is a specialized agency of the United Nations) (é.n.): Why tourism? <http://www2.unwto.org/content/why-tourism>. (2017.04.29.)

Zsótér B. (2007): A Hotel Nonius szolgáltatásait igénybe vevök földrajzi megoszlása. Agrár-és Vidékfejlesztési Szemle, 2 (2): 201-206. 